\title{
ANALISIS MARKETING APPEALS DAN SOURCE OF MESSAGE TERHADAP PENERIMAAN PUBLIK PADA IKLAN PEMBATASAN TRANSAKSI TUNAI
}

\author{
Ibrahim Qamarius \\ Fakultas Ekonomi \\ Universitas Malikussaleh
}

\begin{abstract}
Penelitian ini bertujuan untuk menganalisis marketing appeals dan source of message terhadap penerimaan publik (public acceptance) pada iklan pembatasan transaksi tunai. Penelitian ini berbentuk metode experimental research design dengan analisis statistik deskriptif. Dalam penelitian ini menggunakan 132 orang mahasiswa pada Fakultas Ekonomi Universitas Indonesia sebagai partisipan. Penelitian experimental research design ini merupakan riset penelitian dengan 4 (empat) cell yaitu riset penelitian marketing appeals iklan pembatasan transaksi tunai dalam kondisi $R p$ 50.000.000,00 (lima puluh juta rupiah) dan kondisi Rp 100.000.000,00 (seratus juta rupiah) dengan source of message dari Komisi Pemberantasan Korupsi dan Bank Indonesia berbentuk $2 \times 2$ cell. Temuan penelitian bahwa marketing appeals iklan pembatasan transaksi tunai dalam kondisi $R p$ 100.000.000,00 (seratus juta rupiah) dengan source of message (sumber pesan) Komisi Pemberantasan Korupsi (KPK) mempunyai skor yang lebih tinggi pada hampir semua dependent variable penerimaan publik (public acceptance) dan berpengaruh sangat efektif terhadap penerimaan publik (public acceptance). Untuk itu penelitian ini menyarankan agar pemerintah dan pihak terkait lainnya agar dapat mempertimbangkan hasil penelitian ini dalam melaksanakan sosialisasi ide pembatasan transaksi tunai dan dalam perumusan atau membuat peraturan/perundang-undangan tentang pembatasan transaksi tunai di Indonesia.
\end{abstract}

Keywords:

Marketing appeals, source of message, penerimaan publik, pembatasan transaksi tunai. 


\section{PENDAHULUAN}

Salah satu elemen dalam komunikasi pemasaran adalah advertising atau periklanan, dimana periklanan merupakan salah satu elemen dalam komunikasi pemasaran yang paling dikenal dan didiskusikan secara luas. Periklanan juga merupakan alat promosi yang penting, terutama untuk perusahaan yang memiliki produk dan jasa yang ditargetkan untuk mass consumer market (Belch \& Belch, 2004). Salah satu strategi dalam periklanan adalah pemilihan daya tarik iklan. Daya tarik (appeal) iklan merupakan usaha kreatif yang dilakukan oleh pengiklan untuk memotivasi perilaku atau mempengaruhi sikap konsumen terhadap suatu produk (Gilson dan Berkman, 1980:388). Ditambahkan oleh Belch dan Belch (2001:275), bahwa daya tarik dalam iklan adalah pendekatan yang digunakan untuk menarik perhatian konsumen dan atau mempengaruhi perasaan konsumen terhadap produk yang diiklankan.

Iklan yang menarik adalah iklan yang mempunyai daya tarik, yaitu memiliki kemampuan untuk menarik perhatian pasar (audience) sasaran. Pesan- pesan yang akan disampaikan dapat disajikan dalam gaya penyampaian yang berbeda beda yaitu dengan menampilkan: cuplikan kehidupan individu atau kelompok, gaya hidup individu, fantasi tentang produk, suasana hati (mood), citra seputar produk, musik untuk lebih menghidupkan pesan, simbol kepribadian untuk menciptakan karakter yang mempersonifikasikan produk, memamerkan keahlian dan pengalaman perusahaan dalam menghasilkan produk, bukti bukti ilmiah keunggulan produk, bukti kesaksian dari orang orang terkenal (Tjiptono,1997).

Dalam memformulasikan isi pesan yang terbaik, manajemen harus mencari tahu daya tarik, tema, ide atau unique selling proposition (USP). Dalam hal ini ada 3 (tiga) jenis daya tarik yaitu: (a) Daya tarik rasional; (b) Daya tarik emosional; (c) Daya tarik moral. (Kotler, 2004). Daya tarik rasional merupakan menciptakan daya tarik untuk ketertarikan pribadi audience, bahwa produk memberikan keuntungan sesuai fungsional yang diyakini. Sementara daya tarik emosional menciptakan emosi yang negatif atau positif yang sanggup memotifasikan tindakan pembelian. Sedangkan daya tarik moral terkait dengan sensibilitas audience terhadap apa yang benar dan pantas.

Pesan yang disampaikan oleh sumber yang menarik atau popular terbukti lebih diperhatikan dan diingat audience. Faktor yang membuat sumber dianggap kredibilitas adalah: (a) Keahlian; (b) Kepercayaan; (c) Ketertarikan/kesukaan. Pada dasarnya tujuan dari komunikasi iklan merupakan suatu tugas komunikasi khusus dan tingkat keberhasilan yang harus dicapai terhadap suatu sasaran pada periode tertentu.

Perkembangan di bidang ilmu pengetahuan dan teknologi telah mendorong pula perkembangan ragam kejahatan yang dilakukan oleh pihak-pihak yang tidak bertanggung jawab. Kejahatan dalam suatu wilayah negara maupun lintas batas wilayah negara juga semakin berkembang. Tindak kejahatan ini umumnya melibatkan dan menghasilkan uang dalam jumlah yang besar, dimana uang uang haram tersebut diperoleh pelakunya dengan cara melawan hukum seperti melakukan korupsi, penyuapan, mencuri, merampok, perjudian, prostitusi, memproduksi dan perdagangan narkotika dan obat-obatan terlarang, penyelundupan barang, penyelundupan tenaga kerja, terorisme, membuat dan mengedar uang palsu, illegal logging dan sebagainya.

Untuk mengelabui aparat penegak hukum agar tidak mencurigai uang kotor itu berasal dari hasil tindak pidana kejahatan, maka salah satu cara yang dapat dilakukan 
oleh pelakunya ialah melakukan praktik money laundering (pencucian uang), misalnya dengan membeli saham atau properti, sehingga uang kotor itu nantinya menjadi seolah-olah bersumber dari suatu kegiatan usaha yang sah.

Menurut Lilley (2003), bahwa sebagian besar tindak pidana di bidang ekonomi dilakukan untuk memperoleh satu hal, yaitu uang. Uang atau dana yang diperoleh dari tindak pidana, yang dalam hal ini tindak pidana tersebut akan menjadi sia-sia belaka kecuali apabila uang hasil tindak pidana (dana ilegal) itu dapat disamarkan atau disembunyikan oleh pelakunya sendiri atau dibantu pihak lain, dengan cara mencucinya melalui penyedia jasa keuangan (bank dan non-bank) atau menggunakan sarana lainnya, sehingga uang atau dana hasil tindak pidana yang telah berhasil dicuci itu menjadi kelihatan seolaholah bersumber dari suatu kegiatan yang sah. Dalam hal ini, suatu analogi yang mungkin tepat untuk menggambar proses pencucian uang adalah sebagaimana teori kimia bahwa "logam dapat diubah menjadi emas” (Lilley, 2003:49).

$$
\text { Sastraadmodjo }
$$

mengemukakan bahwa praktek pencucian uang awalnya dikembangkan di Amerika Serikat oleh organisasi kejahatan, termasuk yang dipimpin $\mathrm{Al}$ Capone. Oleh karena penegak hukum di Amerika Serikat mengalami kesulitan membuktikan keterlibatan Al Capone dalam berbagai tindak kejahatan berat termasuk pencucian uang, maka Internal Revenew Service (IRS) menangkap dan memasukkan $\mathrm{Al}$ Capone ke penjara berdasarkan perbuatan melawan hukum di bidang pajak. Memang dalam prakteknya, masalah pelanggaran atau penghindaran pajak (tax evation) lebih mudah dibuktikan ketimbang tindak pidana pencucian uang. Pembuktian tindak pidana pencucian uang tidak mudah karena dalam kegiatan bisnis haram tersebut banyak pihak yang terlibat mulai dari pegawai bank, para eksekutif/manajemen bank, pengacara, akuntan hingga profesional lainnya dari semua tingkatan.

Dalam konteks penegakan hukum, istilah money laundering bukanlah suatu konsep yang sederhana, melainkan sangat rumit karena masalahnya begitu kompleks sehingga cukup sulit untuk merumuskan delik-delik hukumnya (kriminalisasi) secara objektif dan efektif. Hal ini tercermin dari batasan pengertiannya yang cukup banyak dan bervariasi. Batasan pengertian (definisi) money laundering yang relatif tidak sama (berbeda-beda) itu juga terdapat pada negara-negara yang sama-sama memiliki ketentuan (undangundang) anti pencucian uang. Demikian juga halnya di antara lembaga dan organisasi internasional yang kompeten di bidang pencegahan dan pemberantasan tindak pidana pencucian uang (Nasution, 2010).

Dalam memerangi pencucian uang di tingkat internasional terdapat berbagai ketentuan tentang perbankan untuk mencegah money laundering, diantanya "Basle Committee atau Committee on Banking Regulations and Supervisory Practices" yang berkedudukan di Basle, Swiss, mengeluarkan Statement on Prevention of Criminal Use of the Banking System for the Purpose of Money Laundering pada tahun 1988. Secara umum statement menegaskan peran perbankan dan para pimpinan bank dalam mencegah dimanfaatkannya bank oleh para pelaku kejahatan. Statement juga menggarisbawahi kepercayaan masyarakat terhadap perbankan sangat berpengaruh terhadap stabilitas perbankan, dan kepercayaan tersebut dapat terkikis apabila masyarakat mengetahui bahwa suatu bank terlibat dalam kegiatan kejahatan. 
Selain itu, ada lembaga internasional dalam memerangi dan memberantas kejahatan pencucian uang, yaitu Financial Action Task Force on Money Laundering (FATF). Action Task Force on Money Laundering (FATF) adalah satuan tugas internasional dalam memerangi dan memberantas kejahatan pencucian uang yang didirikan tujuh negara industri maju (G-7) di Paris tahun 1989. Meskipun Indonesia bukan anggota kerja sama pemberantasan pencucian uang regional Asia Pasifik (Asia Pacific Group on Money Laundering/APG), Indonesia terikat berbagai rekomendasi Financial Action Task Force on Money Laundering (FATF).

Adapun rekomendasi Financial Action Task Force on Money Laundering (FATF) secara garis besar mencakup kerangka umum rekomendasi ada 4 (empat), yaitu : (1) Peran Sistem Hukum Nasional; (2) Sistem Hukum Pidana dan Penegakan Hukum; (3) Peran Sistem Keuangan dalam Memberantas Tindak Pidana Pencucian Uang; (4) Kerjasama Internasional.

Pada tahun 1990, Financial Action Task Force on Money Laundering (FATF) untuk pertama kalinya mengeluarkan 40 (empat puluh) rekomendasi sebagai suatu kerangka yang komprehensif untuk memerangi kejahatan money laundering. Dimana recommendations tersebut menetapkan prinsip-prinsip untuk penyusunan kebijakan impelementasi oleh setiap negara. Namun demikian, FATF memberikan keleluasaan kepada setiap negara dalam mengimplementasikan rekomendasi dengan melihat kondisi dan sistem hukum yang berlaku di setiap negara.

Sementara untuk memerangi pencucian uang di Indonesia, berbagai peraturan perundang-undangan juga telah dibuat dan telah diterapkan, seperti Peraturan Bank Indonesia, Nomor:
3/10/PBI/2001 jo Peraturan Bank Indonesia Nomor: 3/23/PBI/2001 tentang Prinsip Mengenal Nasabah atau Know Your Customer, Undang-Undang Nomor: 15 Tahun 2002 Tentang Tindak Pidana Pencucian Uang, Tanggal 17 April 2002, Undang-Undang Nomor: 25 Tahun 2003 Tentang Tindak Pidana Pencucian Uang, UndangUndang Nomor 8 Tahun 2010 tentang Pencegahan dan Pemberantasan Tindak Pidana Pencucian Uang dan peraturan perundang-undangan lainnya.

Menurut Qamarius (2011), korupsi dan pencucian uang lainnya di Indonesia sangat sulit diberantas karena orientasi pemberantasan korupsi dan pencucian uang lainnya lebih cenderung pada penindakan/penuntutan daripada pencegahan. Seharusnya antara penindakan/penuntutan dan pencegahan dalam pemberantasan korupsi dan pencucian uang lainnya harus harus dilakukan seimbang. Pengalaman selama ini, lembaga penegakan hukum hanya melakukan penyitaan dan denda terhadap harta hasil korupsi dan pencucian uang lainnya, semua harta dari penyitaan dan denda dimasukkan ke kas negara, kemudia menjadi Anggaran Pendapatan dan Belanja Negara (APBN) lagi, kemudian terjadi lagi korupsi dan pencucian uang lainnya. Sehingga korupsi dan pencucian uang lainnya di Indonesia terus terjadi dan berulang-ulang seperti tiada akhir.

Dari segi biaya, pencegahan jelas lebih murah daripada upaya hukum lainnya. Karena, apabila uang sudah terlanjur dikorupsi dan dicuci, maka diperlukan biaya yang sangat besar untuk mengembalikan uang tersebut kepada negara. Selain itu diperlukan biaya tambahan, seperti biaya pengejaran, pemeriksaan saksi, penjemputan, penahanan dan lainnya. Namun demikian, penuntutan atau penindakan tetap sangat diperlukan untuk menegakkan supremasi 
hukum di Indonesia. Tetapi harus adanya keseimbangan dengan upaya-upaya pencegahan (preventif) di masa yang akan datang. Sehingga upaya-upaya pencegahan terhadap peluang terjadinya korupsi dan pencucian uang lainnya perlu terus ditingkatkan dengan berbagai strategi dan program yang ada, seperti penerapan ide pembatasan transaksi tunai dan sebagainya.

Meskipun sejak awal kemerdekaan Indonesia telah berusaha melakukan upaya pemberantasan korupsi dan pencucian uang lainnya dengan berbagai cara dengan berbagai peraturan/perundang-undangan. Namun, pemberantasan korupsi dan pencucian uang lainnya di Indonesia belum mencapai hasil sebagaimana yang diharapkan. Begitu juga sejak tahun 2001 Indonesia telah melakukan Penerapan Prinsip Mengenal Nasabah atau lebih dikenal umum dengan Know Your Customer Principle (KYC Principle). Namun penerapan prinsip tersebut belum begitu efektif dalam mencegah korupsi dan money laundering (pencucian uang) lainnya di Indonesia. Sehingga ide pembatasan transaksi tunai merupakan salah satu solusi dan diharapkan akan mampu memberi pengaruh yang signifikan terhadap pencegahan korupsi dan money laundering (pencucian uang) lainnya di Indonesia.

Pembatasan Transaksi Tunai adalah suatu mekanisme untuk membatasi transaksi dengan uang tunai, dimana transaksi diatas batas yang ditentukan harus dilakukan sistem perbankan dan lembaga keuangan lainnya. Misalnya transaksi tunai dibatasi Rp 100.000.000,00 (seratus juta) untuk perusahaan dan Rp 50.000.000,00 (lima puluh juta rupiah) untuk pribadi atau perorangan dalam 1 (satu) hari. Dimana semua transaksi dengan uang diatas batas tersebut, harus dilakukan melalui sistem perbankan (Qamarius, 2011).

Dengan pembatasan transaksi tunai yang dikenal juga transaksi non tunai (non cash transaction) tersebut, seluruh bank dan lembaga keuangan lainnya di Indonesia ikut berperan aktif dalam pencegahan korupsi dan money laundering, disamping menjalankan fungsi dan tugas utamanya.

Saat ini, hampir semua pihak telah setuju dengan ide pembatasan transasksi tunai, hal ini terlihat dari berbagai pernyataan pihak terkait seperti Dewan Perwakilan Rakyat Republik Indonesia, Pusat Pelaporan dan Analisa Transaksi Keuangan, Komisi Pemberantasan Korupsi, Kementerian Hukum dan Hak Asasi Manusia, Kementerian Koordinator Bidang Perekonomian, Kementerian Keuangan, Bank Indonesia, Unit Kerja Presiden Bidang Pengawasan dan Pengendalian Pembangunan (UKP4), Badan Pemeriksa Keuangan (BPK) dan berbagai pihak lainnya. Namun sampai saat ini belum bisa memutuskan berapa besaran uang tunai yang dibatasi (Gunawan, 2013). Dalam hal ini belum ada kesepakatan apakah pembatasan transaksi tunai dalam kondisi Rp 50.000.000,00 (lima puluh juta rupiah) atau Rp 100.000.000,00 (seratus juta rupiah). Selain itu pihak mana yang paling bertanggung jawab untuk melakukan sosialisasi atau sebagai sumber pesan (source of message) pada iklan ide pembatasan transaksi tunai tersebut?

Berdasarkan latar belakang di atas, paper ini menganalis bagaimana marketing appeals (daya tarik iklan) dan source of message (sumber pesan) dari Komisi Pemberantasan Korupsi dan Bank Indonesia terhadap public acceptance (penerimaan publik) pada iklan pembatasan transaksi tunai untuk pemberantasan korupsi dan pencucian uang lainnya dan berapa pembatasan transaksi tunai yang diharapkan publik, dalam kondisi Rp 50.000.000,00 (lima puluh juta rupiah) atau kondisi Rp 100.000.000,00 (seratus juta rupiah)?

Tujuan paper ini, pertama adalah untuk mengetahui dan menganalisis 
marketing appeals (daya tarik iklan) dengan source of message (sumber pesan) dari Komisi Pemberantasan Korupsi (KPK) dan Bank Indonesia terhadap public acceptance (penerimaan publik) pada iklan pembatasan transaksi tunai untuk pemberantasan korupsi dan pencucian uang lainnya; kedua, untuk mengetahui dan menganalisis pembatasan transaksi tunai yang diharapkan publik, dalam kondisi Rp 50.000.000,00 (lima puluh juta rupiah) atau kondisi $\mathrm{Rp}$ 100.000.000,00 (seratus juta rupiah); ketiga, memberikan rekomendasi kebijakan untuk pemerintah dan pihak terkait lainnya.

\section{METODE PENELITIAN}

\subsection{Desain Eksperimen}

Desain penelitian yang digunakan dalam penelitian ini adalah desain eksperimen (experimental research design). Desain eksperimen merupakan sekumpulan prosedur yang mengarahkan sebuah penelitian eksperimen dengan melakukan hal-hal yang spesifik seperti variabel independen apa yang harus dimanipulasi, variabel dependen yang mana yang harus diukur, level of treatment yang mana yang akan digunakan, bagaimana memilih test unit dan menyusun test unit tersebut dalam kelompok yang berbeda, bagaimana melakukan kontrol untuk selection bias, dan bagaimana meminimalkan pengaruh dari extraneous variable terhadap hasil eksperimen (Aaker et al., 2003). Desain eksperimen merupakan desain penelitian yang paling tepat dalam menjelaskan hubungan dalam studi ini.

Menurut Neuman (2000), desain eksperimen merupakan desain penelitian yang terkuat dalam menguji hubungan kausalitas yang dikarenakan oleh tiga kondisi yang ada dalam hubungan kausalitas (conditions for causality) yaitu temporal order yaitu harus ada penyebab sebelum ada akibat, association yaitu akibat yang timbul tersebut dikarenakan ada asosiasi yang kuat dengan penyebab atau disebut juga dengan cocomittan variation (dua variabel yang berubah secara bersamaan) dalam studi ini dilakukan dengan memberikan manipulasi, dan eliminating alternative yaitu hubungan tersebut terjadi dikarenakan oleh penyebab tersebut bukan oleh faktor yang lain, dengan melakukan kontrol.

Penelitian eksperimen adalah suatu penelitian yang di dalamnya ditemukan minimal satu variabel yang dimanipulasi untuk mempelajari hubungan sebab-akibat. Oleh karena itu, penelitian eksperimen erat kaitanya dalam menguji suatu hipotesis dalam rangka mencari pengaruh, hubungan, maupun perbedaan perubahan terhadap kelompok yang dikenakan perlakuan (Solso \& MacLin, 2002).

Menurut Cooper \& Schindler (2006), eksperimen merupakan studi yang melibatkan intervensi oleh periset diluar apa yang diharapkan untuk pengukuran. Intervensi ini umumnya adalah manipulasi suatu variabel dalam sebuah latar belakang dan mengamati bagaimana hal itu mempengaruhi pokok masalah yang sedang dikaji (misalnya, orangorang atau entitas fisik). Periset dalam hal ini memanipulasi variabel bebas atau penjelas lalu mengamati apakah variabel terikat yang dihipotesiskan terpengaruh oleh intervensi. Sementara Sugiyono (2008), mendefinisikan penelitian eksperimen dapat diartikan sebagai metode penelitian yang digunakan untuk mencari pengaruh perlakuan tertentu terhadap yang lain dalam kondisi yang terkendalikan.

Sedangkan menurut Arikunto (2010), penelitian eksperimen merupakan penelitian yang dimaksud untuk mengetahui ada tidaknya akibat dari "sesuatu” yang dikenakan pada sunjek selidik. Dengan kata lain penelitian eksperimen mencoba meneliti ada tidaknya hubungan sebab akibat. 
Caranya adalah dengan membandingkan satu atau lebih kelompok eksperimen yang diberi perlakuan dengan satu atau lebih kelompok pembanding yang tidak menerima perlakuan.

Dalam penelitian ini metode yang digunakan adalah experimental research design, dimana dalam penelitian ini mencari pengaruh dari daya tarik pemasaran (marketing appeals) pada iklan ide pembatasan transaksi tunai di Indonesia, baik source of message (sumber pesan) dari Komisi Pemberantasan Korupsi sebagai Policy Benefit Institution dan Bank Indonesia sebagai Policy Execution Institution maupun dalam kondisi Rp 50.000.000,00 (lima puluh juta rupiah) dan kondisi Rp 100.000.000,00 (seratus juta rupiah) terhadap penerimaan publik (public acceptance) pada iklan pembatasan transaksi tunai untuk pemberantasan korupsi dan pencucian uang lainnya. Independent variable dimanipulasi untuk mencari tahu perbedaan pengaruhnya terhadap dependent variable (public acceptance).

Dalam penelitian yang berbentuk experimental research design tersebut berjenis statistical designs dengan menggunakan desain faktorial. Menurut Malhotra (2007), desain faktorial (factorial design) merupakan suatu statistical experimental research yang digunakan untuk mengukur pengaruh dua atau lebih independent variable dalam level yang bervariasi dan interaksi antar variabel.

Penelitian yang menggunakan metode factorial design dapat mengkonseptualisasikan penelitiannya dalam bentuk tabel. Dalam penelitian ini berbentuk two-factorial design, dimana setiap level dari satu variable menampilkan baris dan setiap level dari variable lainnya menampilkan kolom. Penelitian ini menggunakan aspek marketing appeals iklan pembatasan transaksi tunai, dengan source of message (sumber pesan) dari Komisi Pemberantasan Korupsi (Policy Benefit Institution) dan Bank Indonesia (Policy Execution Institution) dalam kondisi Rp 50.000.000,00 (lima puluh juta rupiah) dan kondisi Rp 100.000.000,00 (seratus juta rupiah).

Ada beberapa hal yang harus diperhatikan dalam melakukan experimental research design tersebut yang menggunakan jenis statistical experimental researchfactorial design, yaitu:

a. Partisipan

Menurut Cooper \& Schindler (2006), dalam memilih sampel penelitian eksperimen menggunakan teknik nonprobabilitas, yaitu suatu teknik pengambilan sample yang tidak didasarkan pada rumusan statistik tetapi lebih pada pertimbangan subyektif peneliti dengan didasarkan pada jangkauan dan kedalaman masalah yang ditelitinya. Sedangkan metode yang digunakan dalam pengambilan sampel menggunakan metode random sampling (sampling acak) yaitu pengambilan sampel berdasarkan populasi dari mana sampel diambil merupakan populasi yang homogen yang mengandung satu ciri (Arikunto, 2010).

Dalam menguji perumusan masalah, penelitian ini dilakukan dengan menggunakan 132 partisipan, dimana partisipan yang terpilih adalah partisipan yang cenderung homogen dimana hal ini dilakukan untuk mengurangi selection bias. Dalam penelitian ini 132 partisipan yang dipilih adalah mahasiswa Fakultas Ekonomi Universitas Indonesia (FE-UI), Program Pendidikan Strata 1 (S1) kelas regular dan kelas ekstensi dengan rentang usia 17 tahun sampai dengan 29 tahun. Mereka dianggap mempunyai karakteristik dan perilaku yang sama, dimana para partisipan cenderung mempunyai karakteristik yang sama 
dari sisi demografi seperti usia, pendidikan, status ekonomi dan sosial lainnya. Homogenitas antar kelompok dilihat berdasarkan jenis kelamin dan umur, serta tingkat pendidikan yang diharapkan dapat memberikan respons yang sama terhadap iklan yang ditawarkan. Homogenitas dari partisipan diperlukan agar pengaruh dari setiap independent variable terhadap dependent variable dapat diperbandingkan karena berasal dari karakteristik partisipan yang sama. Partisipan dikelompokkan dalam empat kelompok secara acak dan semuanya mendapatkan kuesioner yang berbeda (between subjects).

b. Independent variable

Independent Variable atau disebut dengan treatment merupakan variabel atau alternatif yang dapat dimanipulasi oleh penulis untuk diketahui pengaruhnya yang dapat diukur dan diperbandingkan (Maholtra, 2007). Sementara menurut Soegandar (2009), independent variable (variabel bebas) adalah sejumlah gejala atau faktor atau unsur yang menentukan atau mempengaruhi ada atau munculnya segala atau faktor atau unsur lain, yang pada gilirannya gejala atau faktor atau unsur kedua itu disebut variabel terikat. Variabel bebas adalah kondisi atau karakteristik yang oleh pengeksperimen dimanipulasikan di dalam rangka untuk menerangkan hubungannya dengan fenomena yang diobeservasi. Dari pengertian tersebut dapat disimpulkan bahwa variabel bebas adalah variabel yang menjadi penyebab munculnya gejala atau kondisi tersebut.

Independent variable yang dimanipulasi oleh penulis yaitu marketing appeals dengan source of message dari Komisi Pemberantasan Korupsi dan Bank Indonesia dalam kondisi Rp 50.000.000,00 dan Rp 100.000.000,00 (tinggi dan rendahnya pembatasan transaksi tunai) dan pengaruhnya terhadap penerimaan public (public acceptance) yang dapat diukur dan diperbandingkan.

Maksud dari marketing appeals yang dimanipulasi adalah sebagai independent variable dimana variable tersebut dimanipulasi tampilannya dan diciptakan sendiri oleh penulis. Dimana penulis menampilkan independent variable tersebut berupa 4 (empat) tipe gambar iklan/print ad, yaitu iklan pembatasan transaksi tunai (iklan yang bersumber dari institusi negara) yang dimanipulasi baik dengan menggunakan Komisi Pemberantasan Korupsi (KPK) maupun Bank Indonesia (BI), dalam kondisi Rp 50.000.000,00 dan Rp 100.000.000,00 (tinggi dan rendahnya pembatasan transaksi tunai). Dengan demikian terdapat 4 (empat) jenis independent variable yang tercipta sebagai stimulus dan diuji untuk mencari perbedaan pengaruhnya terhadap dependent variable (public acceptance).

Untuk tipe iklan yang pertama dipilih dengan menggunakan sebagai sumber pesan dari Komisi Pemberantasan Korupsi (KPK), dengan jumlah yang dibatasi Rp 50.000.000,00 (lima puluh juta rupiah). Sementara untuk tipe iklan yang kedua menggunakan sumber pesan Bank Indonesia sebagai sumber pesan, dengan jumlah yang dibatasi Rp 50.000.000,00 (lima puluh juta rupiah). Untuk tipe iklan yang ketiga dipilih dengan menggunakan sebagai sumber pesan dari Komisi Pemberantasan Korupsi (KPK), dengan jumlah yang dibatasi Rp 100.000.000,00 (seratus juta rupiah). Sedangkan untuk tipe iklan yang ke empat menggunakan sumber pesan Bank Indonesia sebagai sumber pesan, dengan jumlah yang dibatasi Rp 100.000.000,00 (seratus juta 
rupiah). Untuk lebih jelas dapat dilihat pada Gambar 1., Gambar 2., Gambar 3. dan Gambar 4.

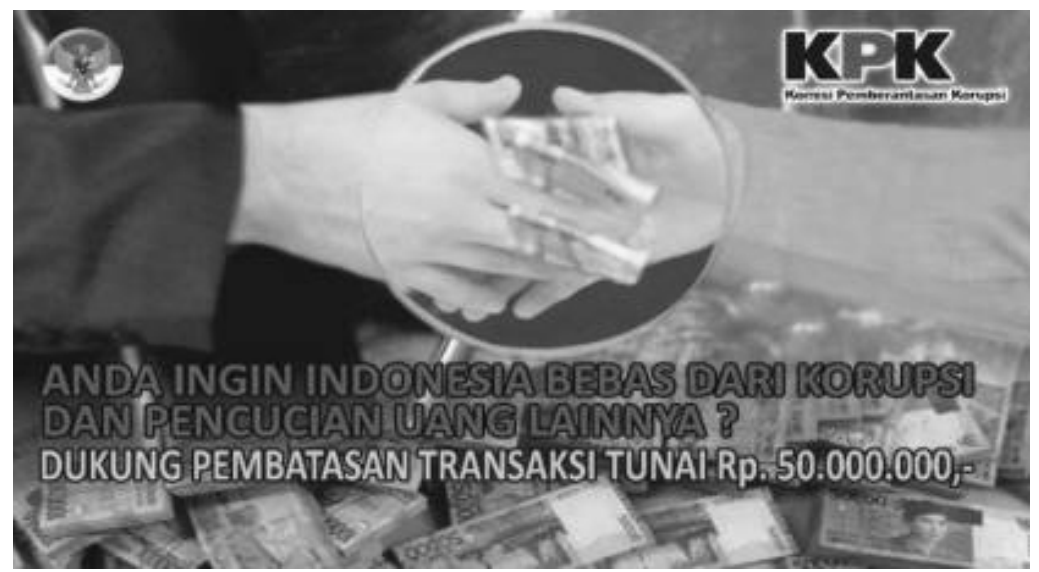

Gambar 1.

Iklan dengan Sumber Pesan Komisi Pemberantasan Korupsi dalam kondisi Rp 50.000.000,00

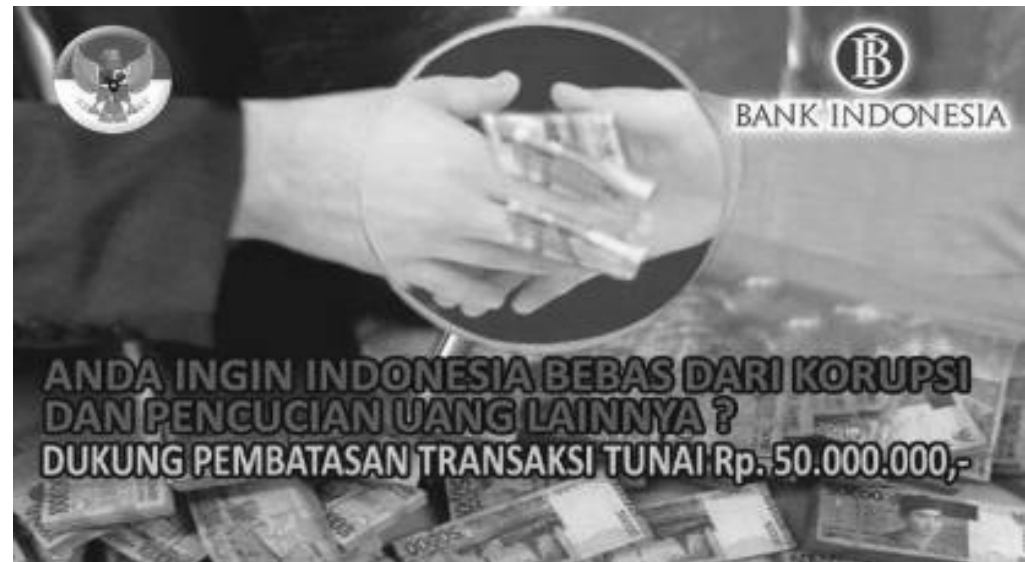

Gambar 2.

Iklan dengan Sumber Pesan Bank Indonesia dalam kondisi Rp 50.000.000,00 


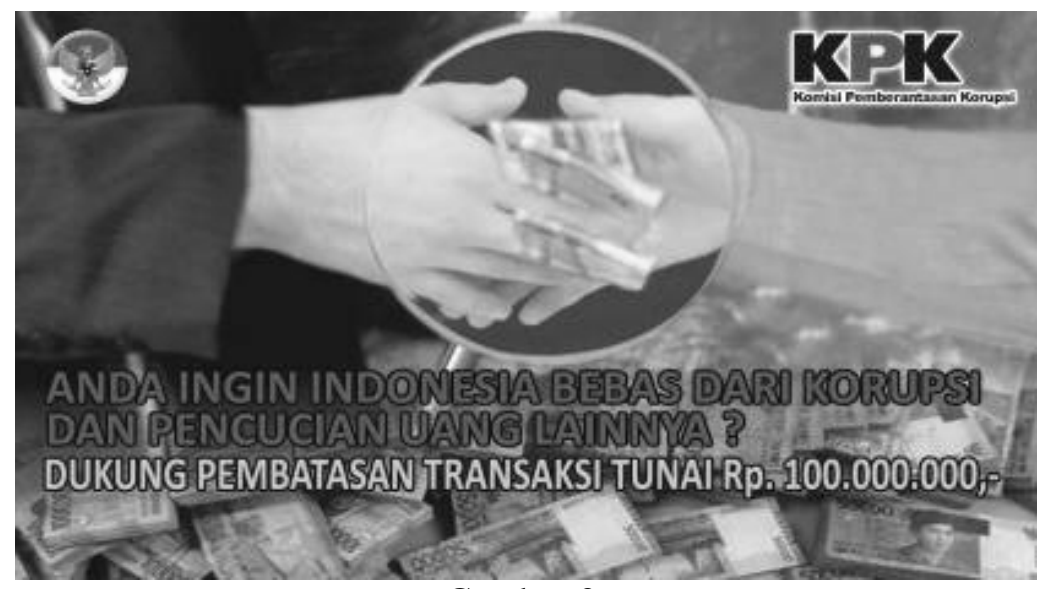

Gambar 3.

Iklan dengan Sumber Pesan Komisi Pemberantasan Korupsi dalam Kondisi Rp 100.000.000,00

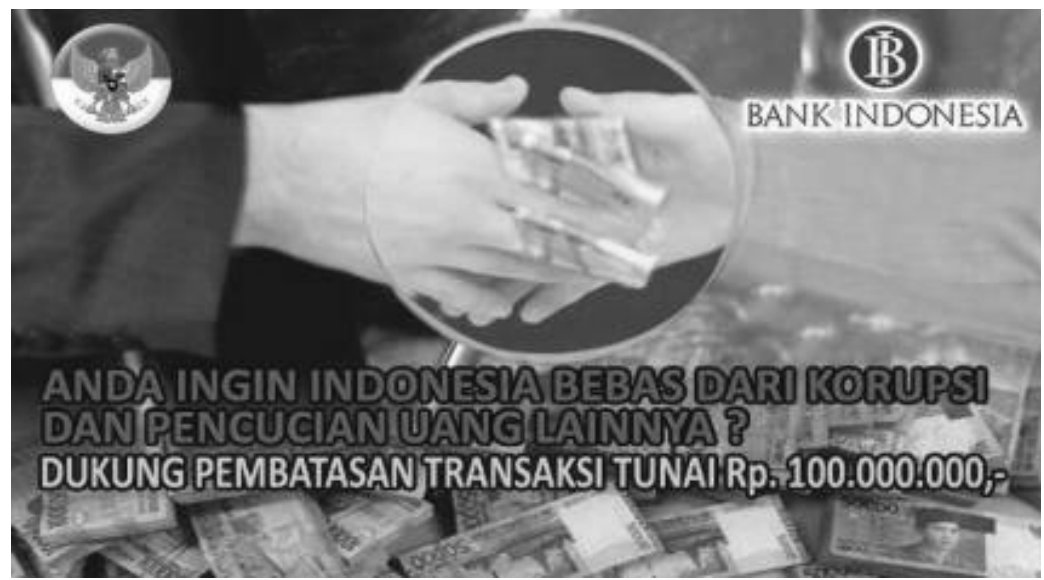

Gambar 4.

Iklan dengan Sumber Pesan Bank Indonesia dalam Kondisi Rp 100.000.000,00

\section{c. Dependent variable}

Dependent variable adalah variabel yang mengukur pengaruh dari independent variable terhadap unit test (Malhotra, 2007). Menurut Hapidin (2010), dependent variable (variabel terikat) yaitu kondisi atau karakteristik yang berubah atau muncul yang tidak muncul ketika pengeksperimen mengintruksi, mengubah atau mengikat. Variabel terikat adalah variabel yang merupakan akibat variabel bebas atau yang dipengaruhi oleh variabel bebas inti.

Beberapa atribut yang dianggap bisa mewakili dimensi yang berkontribusi terhadap penerimaan publik merupakan dependent variable yang diukur untuk melihat dampak dari independent variable (marketing appeals). Dalam penelitian ini dikemukakan beberapa atribut yang bertindak sebagai dependent variable. Atribut-atribut berikut dianggap dapat mewakili dimensi yang berkontribusi terhadap penerimaan publik 
dalam konteks iklan pembatasan transaksi tunai, yang akan diukur dengan menggunakan 6 (enam) skala likert dan open-question:

- Iklan Sangat Menarik (PA1)

- Iklan Sangat Jelas (PA2)

- Mendukung Pembatasan Transaksi Tunai (PA3)

- Bersedia Menandatangani Petisi (PA4)

\subsection{Manipulasi Marketing Appeals}

Sebelum stimulus digunakan, terlebih dahulu dilakukan pre-test untuk memastikan bahwa gambar iklan pembatasan transaksi tunai yang telah dimanipulasi dan ditampilkan adalah memang dianggap iklan yang mengandung unsur dari kedua aspek source of message (Komisi Pemberantasan Korupsi dan Bank Indonesia).

\subsubsection{Pre-test 1 \\ Pre-test 1 dilakukan dengan} menggunakan 17 orang juri, yang terdiri dari dosen pemasaran, pakar iklan dan pemerhati iklan, dimana kepada mereka ditanyakan dugaan mereka terhadap sumber iklan (source of message) yang menggunakan marketing appeals. Terdapat 8 alternatif stimuli gambar iklan pembatasan transaksi tunai yang diolah dan dimanipulasi baik iklan yang menggunakan source of message Komisi Pemberantasan Korupsi maupun Bank Indonesia. Setelah iklan diolah dan dimanipulasi sedemikian rupa, mereka memilih diantara 8 alternatif gambar iklan tersebut, gambar mana yang paling mencerminkan source of message sebagai berikut (Gambar 5. dan Gambar 6.).

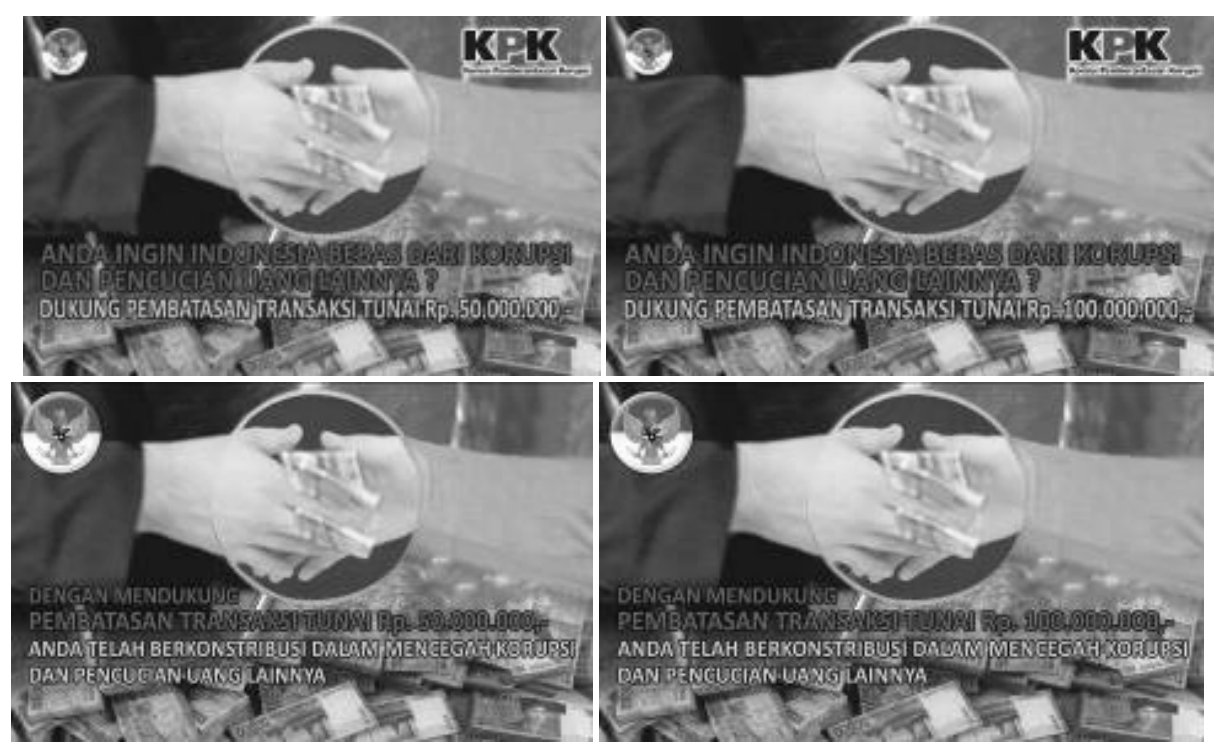

Gambar 5.

Alternatif Stimuli Sumber Iklan Organisasi Non-Profit (Komisi Pemberantasan Korupsi) 


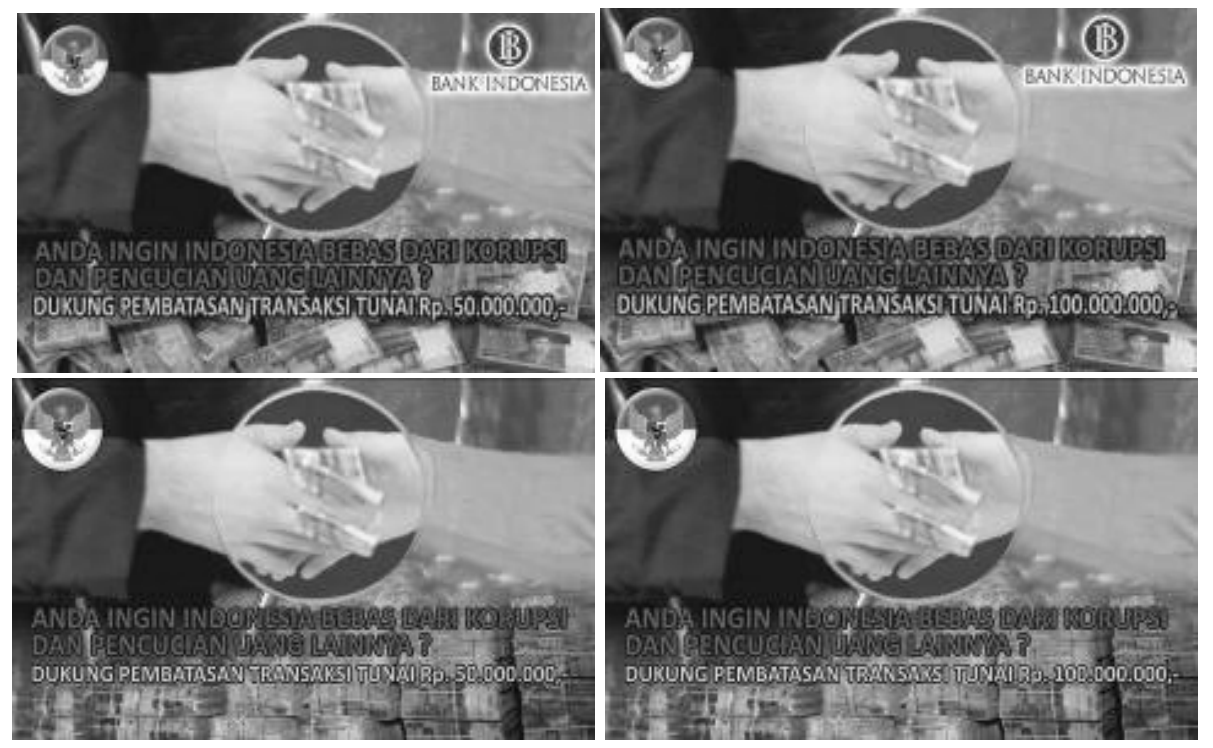

Gambar 6.

Alternatif Stimuli Sumber Iklan Organisasi Non-Profit (Bank Indonesia)

Pada pre-test 1 di atas, iklan yang menggunakan source of message Komisi Pemberantasan Korupsi yang terpilih untuk dilanjutkan pada pre-test 2, karena dianggap lebih jelas memperlihatkan sumber pesan (source of message).

\subsubsection{Pre-test 2}

Setelah dilakukan pre-test 1, selanjutnya untuk memastikan gambar iklan institusi negara yang mana yang dianggap iklan yang mengandung unsur marketing appeals. Kemudian dilanjutkan dengan melakukan pre-test 2 untuk mengetahui apakah masih terdapat kesulitan dalam memahami kuesioner yang diajukan. Pretest 2 dilakukan dengan menggunakan 17 orang sebagai juri, yang terdiri dari dosen pemasaran, pakar pemasaran dan pemerhati iklan. Dimana kepada mereka ditanyakan beberapa item penerimaan publik yang dinilai sesuai dengan marketing appeals dari gambar iklan institusi negara yang ditampilkan. Dari hasil pre-test ini dilakukan revisi sampai kuesioner dapat dipahami dengan jelas.

\subsection{Desain K uesioner}

Berdasarkan hasil pre-test, maka gambar iklan yang telah terpilih tersebut digunakan sebagai stimuli dalam penelitian dan disajikan dalam kuesioner. Kemudian dilanjutkan dengan pertanyaan-pertanyaan mengenai ke empat atribut penerimaan publik (public acceptance) dalam 2 (dua) kondisi, yaitu dalam kondisi Rp 50.000.000,00 dan Rp 100.000.000,00 (tinggi dan rendahnya pembatasan transaksi tunai). Seterusnya dilanjutkan dengan pertanyaan-pertanyaan bersifat filler (pertanyaan yang berbeda/pengalihan), kemudian pertanyaanpertanyaan manipulation check (uji manipulasi) dan pertanyaan-pertanyaan personal/demografi.

\subsection{Pengumpulan Data}

Manipulasi dari independent variable dilakukan dengan memberikan ke empat stimuli yang berbeda kepada partisipan dengan 4 (empat) cell yang berbeda, yang terdiri dari 132 partisipan yang valid, yaitu: 


\subsubsection{Tahap 1}

Aspek Marketing Appeals dengan source of message dari Komisi Pemberantasan Korupsi dan Bank Indonesia dalam kondisi Rp 50.000.000,00 (lima puluh juta rupiah) dan kondisi Rp 100.000.000,00 (seratus juta rupiah) terhadap penerimaan publik (public acceptance).

a. Kelompok partisipan (A) yang menerima stimulus berupa gambar iklan dengan sumber iklan Komisi Pemberantasan Korupsi (KPK) dalam kondisi Rp 50.000.000,00 (lima puluh juta rupiah) direncanakan sebanyak 33 partisipan.

b. Kelompok partisipan (B) yang menerima stimulus berupa gambar iklan dengan sumber iklan Bank Indonesia (BI) dalam kondisi kondisi $\mathrm{Rp}$ 50.000.000,00 (lima puluh juta rupiah), direncanakan sebanyak 33 partisipan.

c. Kelompok partisipan (C) yang menerima stimulus berupa gambar iklan dengan sumber iklan Komisi Pemberantasan Korupsi (KPK) dalam kondisi Rp 100.000.000,00 (seratus juta rupiah) direncanakan sebanyak 33 partisipan.

d. Kelompok partisipan (D) yang menerima stimulus berupa gambar iklan dengan sumber iklan Bank Indonesia (BI) dalam kondisi kondisi Rp 100.000.000,00 (seratus juta rupiah), direncanakan sebanyak 33 partisipan.

\subsubsection{Tahap 2}

Aspek Manipulation Check, dengan source of message dari Komisi Pemberantasan Korupsi dan Bank Indonesia dalam kondisi Rp 50.000.000,00 (lima puluh juta rupiah) dan kondisi Rp 100.000.000,00 (seratus juta rupiah):

a. Kelompok partisipan yang sama pada tahap 1, yaitu partisipan (A) yang menerima stimulus berupa pertanyaan sesuai iklan dengan sumber iklan Komisi Pemberantasan Korupsi (KPK) dalam kondisi Rp 50.000.000,00 (lima puluh juta rupiah) direncanakan sebanyak 33 partisipan.

b. Kelompok partisipan yang sama pada tahap 1, yaitu partisipan (B) yang menerima stimulus berupa pertanyaan sesuai iklan dengan sumber iklan Bank Indonesia (BI) dalam kondisi Rp 50.000.000,00 (lima puluh juta rupiah) direncanakan sebanyak 33 partisipan.

c. Kelompok partisipan yang sama pada tahap 1, yaitu partisipan (C) yang menerima stimulus berupa pertanyaan sesuai iklan dengan sumber iklan Komisi Pemberantasan Korupsi (KPK) dalam kondisi Rp 100.000.000,00 (lima puluh juta rupiah) direncanakan sebanyak 33 partisipan.

d. Kelompok partisipan yang sama pada tahap 1, yaitu partisipan (D) yang menerima stimulus berupa pertanyaan sesuai iklan dengan sumber iklan Bank Indonesia (BI) dalam kondisi Rp 100.000.000,00 (lima puluh juta rupiah) direncanakan sebanyak 33 partisipan.

Partisipan dipilih dalam setiap kelas dan stimuli diacak agar setiap partisipan memperoleh kesempatan yang sama untuk mendapatkan setiap stimuli. Kuesioner dibagi kepada semua partisipan dalam 2 (dua) tahap. Tahap pertama diberikan kuesioner dengan pertanyaan yang berhubungan dengan beberapa atribut yang bertindak sebagai dependent variable. Atribut-atribut tersebut dianggap bias mewakili dimensi yang berkontribusi terhadap penerimaan publik (public acceptance). Pertanyaan dalam kuesioner itu akan diukur dengan menggunakan 6 (enam) skala Likert (Sangat Tidak Setuju, Tidak Setuju, Agak Tidak Setuju, Agak Setuju, Setuju, Sangat Setuju) dan open-question. Pertanyaan-pertanyaan itu adalah sebagai berikut : 
- Menurut saya, gambar iklan sosial diatas sangat menarik (PA1).

- Menurut saya, pesan dalam iklan sosial diatas sangat jelas (PA2).

- Saya bersedia menandatangani petisi yang mendukung Pembatasan Transaksi Tunai Rp 50.000.000,00 (lima puluh juta rupiah), yang diiklankan oleh Komisi Pemberantasan Korupsi agar Indonesia bebas dari korupsi dan pencucian uang lainnya (PA3).

- Saya bersedia menandatangani petisi yang mendukung Pembatasan Transaksi Tunai Rp 50.000.000,00 (lima puluh juta rupiah), yang diiklankan oleh Komisi Pemberantasan Korupsi agar Indonesia bebas dari korupsi dan pencucian uang lainnya (PA4).

Setelah pertanyaan diatas (tahap pertama) selesai di jawab dan dikumpulkan, selanjutnya diberikan kuesioner dengan pertanyaan uji manipulasi (manipulation check). Pertanyaan dalam kuesioner dengan pertanyaan uji manipulasi (manipulation check) itu akan diukur dengan menggunakan skala Guttman, dengan memberi nilai pada setiap jawaban. Untuk jawaban yang benar akan diberikan nilai 1 , dan untuk jawaban yang salah nilainya 0 .

Pertanyaan-pertanyaan untuk uji manipulasi (manipulation check) tersebut adalah sebagai berikut :

- Menurut Anda, organisasi apa yang mengeluarkan iklan pembatasan transaksi tunai tersebut? (MC1)

- Berapakah jumlah pembatasan transaksi tunai yang disampaikan dalam iklan sosial ? (MC2)

- Menurut Anda, apa tujuan dari iklan sosial pembatasan transaksi tunai tersebut ? (MC3)

Setelah partisipan menjawab pertanyaan-pertanyaan tahap 1 dan dikumpulkan, kemudian dilanjutkan dengan tahap 2. Hasil jawaban partisipan dikumpulkan melalui research assistants yang membatu dalam setiap kelas. Partisipan diberikan souvenir berupa ballpoint yang dibagikan bersamaan dengan pembagian kuesioner yang juga dapat digunakan dalam menjawab kuesioner.

\subsection{Pengkodean Data}

Data yang telah terkumpul diberi kode untuk mengorganisasikan proses penginputan data ke dalam program SPSS (Statistical Product and Service Solutions). Pengkodean yang dilakukan oleh penulis adalah sebagaimana terlihat pada Tabel 1 . berikut ini. 
Tabel 1.

Tabel Pengkodean Data

\begin{tabular}{|c|c|c|c|}
\hline No & Keterangan & Kode & Nomor Kode \\
\hline 1 & Rp 50.000.000,00 - KPK & A & 001-033 \\
\hline 2 & Rp 50.000.000,00 - BI & $\mathrm{B}$ & $001-033$ \\
\hline 3 & Rp 100.000.000,00 - KPK & C & $001-033$ \\
\hline 4 & Rp 100.000.000,00 - BI & $\mathrm{D}$ & 001-033 \\
\hline \multirow[t]{5}{*}{5} & Item Penerimaan Publik & & \\
\hline & a. Iklan sangat menarik & PA1 & \\
\hline & b. Iklan sangat jelas & PA2 & \\
\hline & c. Mendukung pembatasan transaksi tunai & PA3 & \\
\hline & b. Bersedia menandatangani petisi & PA4 & \\
\hline \multirow[t]{5}{*}{6} & Item Manipulation Check & & \\
\hline & a. Organisasi yang mengeluarkan iklan & MC1 & \\
\hline & b. Jumlah pembatasan transaksi tunai & & \\
\hline & c. Tujuan pembatasan transaksi tunai & & \\
\hline & d. Bersedia menandatangani petisi & MC2 & \\
\hline
\end{tabular}

Sumber : Data diolah

\subsection{Metode Analisis Data}

Riset eksperimen ini merupakan riset penelitian yang berbentuk 2 (dua) aspek marketing appeals, yaitu marketing appeals iklan pembatasan transaksi tunai dalam kondisi Rp 50.000.000,00 (lima puluh juta rupiah) dan kondisi Rp 100.000.000,00 (seratus juta rupiah) dan 2 (dua) sumber pesan (source of message) Komisi Pemberantasan Korupsi dan Bank Indonesia terhadap penerimaan publik (public acceptance).

Dengan demikian, aspek marketing appeals terhadap penerimaan publik dalam kondisi Rp 50.000.000,00 (lima puluh juta rupiah) kondisi Rp
100.000.000,00 (seratus juta rupiah). Dimana marketing

appeals yang terdiri dari 2 level yaitu dalam kondisi Rp 50.000.000,00 (lima puluh juta rupiah) dan kondisi $\mathrm{Rp}$ 100.000.000,00 (seratus juta rupiah) dan 2 level sumber pesan (source of message) yaitu Policy Benefit Institution (Komisi Pemberantasan Korupsi) dan Policy Execution Institution (Bank Indonesia). Dengan demikian, dalam penelitian studi eksperimen ini menggunakan 2 × $2=4$ cell, seperti pada Tabel 2. di bawah ini.

Tabel 2.

Aspek Marketing Appeals dan Source of Message

\begin{tabular}{|c|c||c|}
\hline \multirow{2}{*}{$\begin{array}{c}\text { Marketing Appeals } \\
\text { Pembatasan Transaksi Tunai }\end{array}$} & Policy Benefit Institution (KPK) & Policy Execution Institution (BI) \\
\cline { 2 - 3 } & $\mathrm{A}$ & $\mathrm{B}$ \\
\hline \hline Rp 50.000.000,00 & $\mathrm{C}$ & $\mathrm{D}$ \\
\hline \hline Rp 100.000.000,00 & & \\
\hline
\end{tabular}

Sumber : Data diolah 
Sedangkan riset penelitian yang berbentuk manipulation check, dengan source of message dari Komisi Pemberantasan Korupsi dan Bank Indonesia dalam kondisi Rp 50.000.000,00 (lima puluh juta rupiah) dan kondisi Rp 100.000.000,00 (seratus juta rupiah).

Dalam penelitian ini, pertama akan mencoba menggambarkan profil partisipan dari sisi demografi, seperti usia, jenis kelamin dan status pernikahan. Kemudian dilanjutkan dengan pertanyaan-pertanyaan manipulation check, yaitu: (a) Organisasi apa yang mengeluarkan iklan pembatasan transaksi tunai tersebut; (b) Berapakah jumlah pembatasan transaksi tunai yang disampaikan dalam iklan sosial; (c) Apa tujuan dari iklan sosial pembatasan transaksi tunai tersebut?

Penerimaan publik (public acceptance) terbentuk dari dimensi yang diwakili oleh beberapa atribut. Pertama, akan dilakukan analisa penerimaan publik (public acceptance) dari ke empat stimulus berupa gambar iklan institusi negara (iklan pembatasan transaksi tunai) yang dimanipulasi. Sebelumnya akan dipastikan terlebih dahulu apakah terdapat perbedaan besarnya rata-rata dalam setiap sumber pesan yang terkandung dalam iklan institusi negara tersebut yang telah dimanipulasi antara unsur Policy Benefit Institution (Komisi Pemberantasan Korupsi) dan Policy Execution Institution (Bank Indonesia). Langkah selanjutnya adalah analisa yang dilakukan dengan kombinasi antara stimulus berupa gambar iklan institusi negara (iklan pembatasan transaksi tunai) yang dimanipulasi dengan stimulus dalam kondisi Rp 50.000.000,00 (lima puluh juta rupiah) dan kondisi Rp 100.000.000,00 (seratus juta rupiah). Disini akan terlihat bagaimana perbedaan penerimaan publik (public acceptance) yang timbul atas stimulus marketing appeal dalam masing-masing kondisi yang berbeda baik kondisi Rp 50.000.000,00 (lima puluh juta rupiah) dan kondisi Rp 100.000.000,00 (seratus juta rupiah).

Kemudian dilanjutkan dengan analisa berikutnya yaitu analisa dengan kombinasi antara stimulus berupa gambar iklan institusi negara (iklan pembatasan transaksi tunai) yang dimanipulasi dengan stimulus dalam kondisi Rp 50.000.000,00 (lima puluh juta rupiah) dan kondisi Rp 100.000.000,00 (seratus juta rupiah).

Disini akan terlihat bagaimana perbedaan penerimaan publik (public acceptance) yang timbul atas stimulus marketing appeals dalam masing-masing kondisi yang berbeda. Dalam kondisi Rp 50.000.000,00 (lima puluh juta rupiah) dan kondisi Rp 100.000.000,00 (seratus juta rupiah), penulis akan mengumumkan pada partisipan dalam bentuk informasi bahwa hasil penelitian tersebut akan ditayangkan/dipresentasikan, maka diperlukan kamera perekam untuk mendokumentasikan kegiatan dalam pengisian kuesioner oleh partisipan. Hasil analisa tersebut akan menjawab perumusan masalah seperti yang telah diuraikan sebelumnya.

Keseluruhan analisa tersebut dilakukan dengan mencari nilai mean dari respon yang didapat. Dalam menguji pengaruh unsur Policy Benefit Institution (Komisi Pemberantasan Korupsi) dan Policy Execution Institution (Bank Indonesia) dalam kondisi Rp 50.000.000,00 (lima puluh juta rupiah) dan kondisiRp 100.000.000,00 (seratus juta rupiah) digunakan metode analisa statistik deskriptif. Dalam penelitian ini, dependent variable adalah atribut yang mewakili dimensi yang berkontribusi terhadap penerimaan publik. 
Data dari dependent variable ini berupa data metric dan diukur dengan menggunakan skala interval atau skala rasio. Dalam pengukuran menggunakan skala semantic differential (6 scale) dengan asumsi bahwa skala 6 tersebut sudah cukup menggambarkan gradasi persepsi partisipan atas dependent variable yang diukur. Sedangkan data dari manipulation check (uji manipulasi) akan diukur dengan menggunakan skala Guttman, yaitu dengan memberi nilai pada setiap jawaban. Untuk jawaban yang benar akan diberikan nilai 1 , dan untuk jawaban yang salah nilainya 0 .

\section{HASIL DAN ANALISIS}

\subsection{Studi Eksperimen}

Penelitian ini membahas mengenai aspek marketing appeals yaitu pembatasan transaksi tunai dalam kondisi Rp 50.000.000,00 (lima puluh juta rupiah) dan kondisi Rp 100.000.000,00 (seratus juta rupiah) dan aspek source of message (sumber pesan) yaitu Komisi Pemberantasan Korupsi dan Bank Indonesia) terhadap penerimaan publik (public acceptance). Dalam studi ini meliputi variabel marketing appeals terdiri dari 2 (dua) tipe yaitu pembatasan transaksi tunai, dalam kondisi Rp 50.000.000,00 (lima puluh juta rupiah) dan kondisi Rp 100.000.000,00 (seratus juta rupiah), serta 2 (dua) tipe source of message yaitu Komisi Pemberantasan Korupsi dan Bank Indonesia. Dengan demikian penelitian ini terdiri dari $2 \times 2=4$ cell.

\subsection{Profil Partisipan}

Jumlah total partisipan yang didapat dalam penelitian ini adalah sebanyak 132 partisipan eksperimen berdasarkan cell-nya yang dapat dilihat pada Tabel 3. berikut ini.

Tabel 3.

Jumlah Partisipan Eksperimen Berdasarkan Cell

\begin{tabular}{|c||c||c||}
\hline \multirow{2}{*}{$\begin{array}{c}\text { Marketing Appeals } \\
\text { Pembatasan Transaksi } \\
\text { Tunai }\end{array}$} & $\begin{array}{c}\text { Solicy Benefit Institution } \\
\text { (KPK) }\end{array}$ & $\begin{array}{c}\text { Policy Execution } \\
\text { Institution (BI) }\end{array}$ \\
\hline \hline Rp 50.000.000,00 & 33 & 33 \\
\hline Rp 100.000.000,00 & 33 & 33 \\
\hline Total & 66 & 66 \\
\hline
\end{tabular}

Sumber : Data diolah

Dari sisi demografi, ada beberapa hal yang dapat dilihat dalam penelitian ini, yaitu: usia, jenis kelamin dan status pernikahan partisipan. Untuk data pendidikan, pekerjaan dan pendapatan partisipan tidak dimasukkan dalam penelitian ini, karena semua partisipan adalah mahasiswa pada Fakultas Ekonomi Universitas Indonesia.

a. Usia partisipan

Dari penelitian yang dilakukan, secara total diperoleh persentase partisipan terbesar adalah pada kelompok usia 19 
tahun (45,5\%), 20 tahun (27,3\%), 21 tahun (11,4\%), 18 tahun (4,5\%), 17 tahun (0,8 \%), 23 tahun (0,8 \%), 24 tahun $(0,8 \%), 26$ tahun $(0,8 \%), 29$ tahun $(0,8$ $\%)$.

b. Jenis kelamin

Jenis kelamin partisipan dalam penelitian ini didominasi oleh wanita. Dimana secara total diperoleh presentase partisipan terbanyak adalah berjenis kelamin wanita $(62,1 \%)$ dan pria sebanyak (37,9\%).

c. Status pernikahan

Partisipan dalam penelitian ini pada umumnya belum menikah (93,9\%), yang sudah menikah hanya sebanyak (6,1\%).

\subsection{Analisis Statistik Deskriptif}

Analisis deskriptif bertujuan mengubah kumpulan data mentah menjadi mudah dipahami dalam bentuk informasi yang lebih ringkas (Istijanto, 2009).

\subsubsection{Analisis Deskriptif - Stimulus Source of Message \\ Dalam perbandingan secara} deskriptif seperti pada Tabel 4. diperoleh hasil dengan rata-rata terbesar adalah pada iklan yang menggunakan marketing appeals dengan source of message (sumber pesan) dari Komisi Pemberantasan Korupsi (KPK) yaitu PA3 (4,8939), PA4 $(4,7121)$, PA2 $(4,3788)$ dan PA1 $(4,2576)$. Sementara iklan yang menggunakan marketing appeals dengan source of message (sumber pesan) dari Bank Indonesia hanya memiliki hasil rata-rata terbesar pada PA3 $(4,2879)$ dan PA4 $(4,2879)$.

Berikut adalah Tabel 4. yang menunjukkan tentang perbedaan mean untuk masing-masing dependent variable (public acceptance - PA1 PA2, PA3 dan PA4) dalam iklan yang menggunakan unsur marketing appeals dengan source of message (sumber pesan) dari Komisi Pemberantasan Korupsi dan Bank Indonesia.

Tabel 4

Analisis Statistik Deskriptif - Perbedaan Mean Penerimaan Publik Source of Message (KPK dan BI) dalam Berbagai Kondisi

\begin{tabular}{||l|r|r||r|r|}
\hline \multirow{2}{*}{\multicolumn{1}{|c|}{ Public Acceptance }} & \multicolumn{2}{c|}{$\begin{array}{c}\text { Policy Benefit } \\
\text { Institution (KPK) }\end{array}$} & \multicolumn{2}{c|}{$\begin{array}{c}\text { Policy Execution } \\
\text { Institution (BI) }\end{array}$} \\
\cline { 2 - 5 } & \multicolumn{1}{|c|}{ Mean } & \multicolumn{1}{c|}{ S. Dev } & \multicolumn{1}{c|}{ Mean } & \multicolumn{1}{c|}{ S. Dev } \\
\hline \hline Iklan sangat menarik (PA1) & 4.2576 & .77083 & 3.3333 & 1.15470 \\
\hline \hline Iklan sangat jelas(PA2) & 4.3788 & .69648 & 3.4697 & 1.08443 \\
\hline \hline Mendukung pembatasan transaksi tunai (PA3) & 4.8939 & .74687 & 4.2879 & 1.30990 \\
\hline \hline Bersedia menandatangani petisi(PA4) & 4.7121 & .87293 & 4.2424 & 1.41487 \\
\hline \hline
\end{tabular}

Sumber : Data diolah

\subsubsection{Analisis Statistik Deskriptif - Stimulus Marketing Appeals}

Secara deskriptif dapat dilihat bahwa penggunaan marketing appeals pembatasan transaksi tunai dengan sumber pesan (source of message) dari Komisi Pemberantasan Korupsi (KPK) dalam kondisi Rp 100.000.000,00 (seratus juta rupiah) mempunyai skor yang lebih tinggi untuk hampir semua atribut 
penerimaan publik dibandingkan dengan kondisi Rp 50.000.000,00 (lima puluh juta rupiah) yang menggunakan source of message (sumber pesan) Komisi Pemberantasan Korupsi dan sumber pesan (source of message) dari Bank Indonesia baik dalam kondisi Rp 50.000.000,00 (lima puluh juta rupiah) maupun kondisi $\mathrm{Rp}$ 100.000.000,00 (seratus juta rupiah).

Dalam perbandingan deskriptif masing-masing dependent variable (public acceptance) diperoleh hasil bahwa iklan yang menggunakan unsur marketing appeals terbesar terdapat pada iklan pembatasan transaksi tunai dengan sumber pesan (source of message) dari Komisi Pemberantasan Korupsi (KPK) dalam kondisi Rp 100.000.000,00 (seratus juta rupiah) yaitu PA3 $(5,1818), \quad$ PA4 $(4,8485)$ dan PA2 (4,4242). Sementara iklan pembatasan transaksi tunai dengan sumber pesan (source of message) Komisi Pemberantasan Korupsi (KPK) dalam kondisi Rp 50.000.000,00 (lima puluh juta rupiah) diperoleh hasil terbesar pada PA3
(4,6061), PA4 yaitu $(4,5758)$ dan PA2 (4,3333). Untuk iklan pembatasan transaksi tunai dengan sumber pesan (source of message) dari Bank Indonesia dalam kondisi Rp 50.000.000,00 (lima puluh juta rupiah) diperoleh hasil terbesar pada PA3 yaitu (4,5152) dan PA4 (4,4242). Sedangkan iklan pembatasan transaksi tunai Bank Indonesia dalam kondisi Rp 100.000.000,00 (seratus juta rupiah) hanya diperoleh hasil terbesar pada PA3 yaitu $(4,0606)$ dan PA4 $(4,0606)$.

Berikut adalah Tabel 5. yang menunjukkan tentang perbedaan mean untuk masing-masing dependent variable (public acceptance) dalam iklan yang menggunakan unsur marketing appeals pembatasan transaksi tunai dengan sumber pesan (source of message) dari Komisi Pemberantasan Korupsi (KPK) dan Bank Indonesia baik dalam kondisi Rp 50.000.000,00 (lima puluh juta rupiah) maupun kondisi Rp 100.000.000,00 (seratus juta rupiah).

Tabel 5.

Analisis Statistik Deskriptif - Stimulus Marketing Appeals

\begin{tabular}{|c|c|c|c|c|c|}
\hline \multirow{3}{*}{$\begin{array}{c}\text { Marketing Appeals } \\
\text { Pembatasan Transaksi Tunai }\end{array}$} & \multirow[t]{3}{*}{ PA } & \multicolumn{4}{|c|}{ Source of Message } \\
\hline & & \multicolumn{2}{|c|}{ Policy Benefit Institution (KPK) } & \multicolumn{2}{|c|}{ Policy Execution Institution (BI) } \\
\hline & & Mean & S. Dev & Mean & S. Dev \\
\hline \multirow[t]{4}{*}{ Rp 50.000.000,00 } & PA1 & 4.2424 & .43519 & 3.6364 & .99430 \\
\hline & PA2 & 4.3333 & .59512 & 3.8485 & 1.09320 \\
\hline & PA3 & 4.6061 & .70442 & 4.5152 & .97215 \\
\hline & PA4 & 4.5758 & .70844 & 4.4242 & 1.22552 \\
\hline \multirow[t]{4}{*}{ Rp 100.000.000,00 } & PA1 & 4.2727 & 1.09320 & 3.0303 & 1.23705 \\
\hline & PA2 & 4.4242 & 1.05349 & 3.0909 & .94748 \\
\hline & PA3 & 5.1818 & 1.00000 & 4.0606 & 1.56004 \\
\hline & PA4 & 4.8485 & 1.17985 & 4.0606 & 1.57994 \\
\hline
\end{tabular}

Sumber : Data diolah

Dalam perbandingan Tabel 5 . tersebut diatas secara umum dapat dilihat bahwa:

a. Dalam kondisi Rp 50.000.000,00 (lima puluh juta rupiah) untuk iklan dengan sumber pesan dari Komisi Pemberantasan Korupsi (KPK) dalam iklan pembatasan transaksi tunai tersebut mempunyai skor 
yang lebih tinggi dibandingkan dengan sumber pesan dari Bank Indonesia dalam iklan pembatasan transaksi tunai untuk hampir semua atribut penerimaan publik (public acceptance).

b. Dalam kondisi Rp 100.000.000,00 (seratus juta rupiah) untuk iklan dengan sumber pesan dari Komisi Pemberantasan Korupsi (KPK) dalam iklan pembatasan transaksi tunai tersebut mempunyai skor yang lebih tinggi dibandingkan dengan sumber pesan dari Bank Indonesia dalam iklan pembatasan transaksi tunai untuk hampir semua atribut penerimaan publik (public acceptance).

\subsection{Manipulation Check}

Uji manipulasi (manipulation check)

dalam eksperimen dilakukan untuk mengetahui perbedaan yang maksimal dalam kelompok-kelompok eksperimen. Pengukuran dalam uji manipulasi dilakukan agar subjek secara akurat dapat memiliki perbedaan dengan subjek lainnya pada perlakuan variabel (Sekaran, 2003).

Analisa statistik deskriptif uji manipulasi (manipulation check) dalam konteks iklan pembatasan transaksi tunai dengan source of message (sumber pesan) dari Komisi Pemberantasan Korupsi dan Bank Indonesia dalam kondisi Rp 50.000.000,00 (lima puluh juta rupiah) maupun kondisi Rp 100.000.000,00 (seratus juta rupiah) adalah menggunakan kuesioner dengan jawaban benar atau salah, yaitu:
a. Organisasi Yang Mengeluarkan Iklan (MC1)
b. Jumlah Pembatasan Transaksi Tunai (MC2)
c. Tujuan Pembatasan Transaksi Tunai (MC2)

Dalam perbandingan secara deskriptif, diperoleh hasil uji manipulasi (manipulation check) seperti dalam Tabel 6.
Yang menunjukkan tentang perbedaan mean untuk masing-masing uji manipulasi (manipulation check - MC1, MC2 dan MC3) dalam iklan yang menggunakan unsur marketing appeals dengan source of message(sumber pesan)dari Komisi Pemberantasan Korupsi dan Bank Indonesia.

Berikut adalah Tabel 6. yang menunjukkan tentang perbedaan mean untuk masing-masing dependent variable (public acceptance) uji manipulasi (manipulation check) dalam iklan yang menggunakan unsur marketing appeals pembatasan transaksi tunai dengan sumber pesan (source of message) dari Komisi Pemberantasan Korupsi (KPK) dan Bank Indonesia baik dalam kondisi Rp 50.000.000,00 (lima puluh juta rupiah) maupun kondisi Rp 100.000.000,00 (seratus juta rupiah). 
Tabel 6.

Analisis Statistik Deskriptif - Manipulation Check

\begin{tabular}{|c|c|c|c|c|c|}
\hline \multirow{3}{*}{$\begin{array}{c}\text { Marketing Appeals } \\
\text { Pembatasan Transaksi Tunai }\end{array}$} & \multirow[t]{3}{*}{ MC } & \multicolumn{4}{|c|}{ Source of Message } \\
\hline & & \multicolumn{2}{|c|}{ Policy Benefit Institution (KPK) } & \multicolumn{2}{|c|}{ Policy Execution Institution (BI) } \\
\hline & & Mean & S. Dev & Mean & S. Dev \\
\hline \multirow[t]{3}{*}{ Rp 50.000.000,00 } & MC 1 & .9697 & 1.17408 & 9697 & 17408 \\
\hline & MC 2 & 1.0000 & . 00000. & .9394 & 24231 \\
\hline & MC 3 & 1.0000 & .00000 & .9394 & .24231 \\
\hline \multirow[t]{3}{*}{ Rp 100.000.000,00 } & MC 1 & .9091 & 29194 & .6970 & .46669 \\
\hline & MC 2 & .9697 & .17408 & .9697 & .17408 \\
\hline & MC 3 & .9091 & .29194 & .9091 & .29194 \\
\hline
\end{tabular}

Sumber : Data diolah

Dalam Tabel 6. diatas, perbandingan deskriptif masing-masing uji manipulasi (manipulation check) diperoleh hasil bahwa iklan yang menggunakan marketing appeals pembatasan transaksi tunai dengan sumber pesan (source of message) dari Komisi Pemberantasan Korupsi (KPK) dalam kondisi Rp 50.000.000,00 (lima puluh juta rupiah) diperoleh hasil terbesar pada MC2 $(1,000)$, MC3 $(1,000)$, dan MC1 $(0,9697)$. Sementara iklan pembatasan transaksi tunai dengan sumber pesan (source of message) Bank Indonesia dalam kondisi Rp 50.000.000,00 (lima puluh juta rupiah) diperoleh hasil terbesar pada MC1 (0,9697), MC2 yaitu $(0,9394)$ dan MC3 (0,9394). Untuk iklan pembatasan transaksi tunai dengan sumber pesan (source of message) dari Komisi Pemberantasan Korupsi (KPK) dalam kondisi Rp 50.000.000,00 (lima puluh juta rupiah) diperoleh hasil terbesar pada MC2 yaitu (0,9697), MC1 (0,9091) dan MC3 (0,9091). Sedangkan iklan pembatasan transaksi tunai Bank Indonesia dalam kondisi Rp 100.000.000,00 (seratus juta rupiah) hanya diperoleh hasil terbesar pada MC2 yaitu (0,9697), MC3 (0,9091) dan MC1 $(0,6970)$.

\subsection{Analisis}

Dari data hasil analisis statistik deskriptif, iklan pembatasan transaksi tunai, yang mengunakan unsur source of message terdapat perbedaan rata-rata (mean) terbesar pada iklan yang menggunakan marketing appeals dengan source of message (sumber pesan) dari Komisi Pemberantasan Korupsi (KPK) yaitu PA3 (4,8939), PA4 (4,7121), PA2 $(4,3788)$ dan PA1 (4,2576). Sedangkan iklan yang menggunakan marketing appeals dengan source of message (sumber pesan) dari Bank Indonesia hanya memiliki hasil ratarata (mean) terbesar pada PA3 (4,2879), PA4 $(4,2879)$, PA2 $(3,4697)$, dan PA1 $(3,3333)$.

Dengan demikian, terlihat bahwa iklan pembatasan transaksi tunai yang menggunakan source of message (sumber pesan) dari Komisi Pemberantasan Korupsi (KPK) memiliki hasil rata-rata lebih besar dibandingkan iklan yang menggunakan marketing appeals dengan source of message (sumber pesan) dari Bank Indonesia.

Sedangkan data hasil analisis statistik deskriptif, iklan pembatasan transaksi tunai yang menggunakan unsur marketing appeals seperti pada Tabel 4 . diatas terdapat perbedaan mean $(\mathrm{M})$, dimana penggunaan source of message 
(Komisi Pemberantasan Korupsi) dalam iklan pembatasan transaksi tunai (M-PA1= 4,2578; $\mathrm{M}-\mathrm{PA} 2=4,3788 ; \mathrm{M}-\mathrm{PA} 3=4,8939 ; \mathrm{PA} 4=$ 4,7121) memiliki mean yang lebih besar dibandingkan dengan penggunaan source of message Bank Indonesia (M-PA1= 3,3333; $\mathrm{M}-\mathrm{PA}=3,4697 ; \mathrm{M}-\mathrm{PA} 3=4,2879$; M-PA4= 4,2424) dalam iklan pembatasan transaksi tunai.

source of message dari Komisi Pemberantasan Korupsi dalam iklan pembatasan transaksi tunai dianggap lebih efektif dalam mempengaruhi penerimaan publik secara signifikan. Temuan dalam penelitian ini bahwa iklan pembatasan transaksi tunai yang menggunakan source of message dari Komisi Pemberantasan Korupsi dianggap lebih efektif dalam mempengaruhi penerimaan publik (M-PA1= 4,2578; M-PA2= 4,3788; M-PA3= 4,8939; PA4= 4,7121) secara keseluruhan pada iklan pembatasan transaksi tunai di Indonesia.

$$
\text { Marketing appeals iklan }
$$

pembatasan transaksi tunai dengan source of message dari Komisi Pemberantasan Korupsi dianggap lebih efektif dalam mempengaruhi penerimaan publik, hal ini dapat disebabkan karena citra Komisi Pemberantasan Korupsi (KPK) yang dianggap partisipan lebih baik daripada Bank Indonesia, sehingga lebih dipercaya oleh partisipan. Selain itu Komisi Pemberantasan Korupsi (KPK) dianggap lebih populer (dikenal) oleh partisipan daripada Bank Indonesia. Kredibilitas sebuah institusi negara sangatlah penting untuk diperhatikan agar publik memiliki rasa trust (kepercayaan) untuk penerimaan publik terhadap lembaga tersebut. Penulis juga merasa yakin jika suatu institusi negara memiliki citra yang baik dan memiliki kredibilitas yang tinggi serta cukup dikenal, maka pengaruh penggunaan marketing appeals iklan pembatasan transaksi tunai dengan source of message dari Komisi Pemberantasan Korupsi dalam iklan sosial dapat lebih efektif.

Begitu juga data hasil analisis statistik deskriptif, iklan sosial yang menggunakan stimulus kondisi Rp 100.000.000,00 (seratus juta rupiah) dalam iklan pembatasan transaksi tunai tersebut seperti Tabel 5. diatas terdapat perbedaan mean (M) dari iklan dengan sumber pesan dari Komisi Pemberantasan Korupsi (KPK), yaitu (M-PA1= 4,2727; M-PA2= 4,4242; $\mathrm{M}-\mathrm{PA3}=\quad 5,1818 ; \quad \mathrm{M}-\mathrm{PA} 4=\quad 4,8485)$ memiliki mean yang lebih besar dibandingkan dengan penggunaan stimulus kondisi Rp 100.000.000,00 (seratus juta rupiah) dengan source of message dari Bank Indonesia (M-PA1=3,0303; M-PA2=3,0909; $\mathrm{M}-\mathrm{PA} 3=4,0606$; M-PA4=4,0606).

Sementara data hasil analisis statistik deskriptif, iklan pembatasan transaksi tunai yang menggunakan stimulus kondisi Rp 50.000.000,00 (lima puluh juta rupiah) dalam iklan pembatasan transaksi tunai dalam Tabel 5 . tersebut diatas terdapat perbedaan mean (M) dari iklan dengan sumber pesan dari Komisi Pemberantasan Korupsi (KPK) dalam iklan pembatasan transaksi tunai, yaitu (MPA1=4,2424; $\mathrm{M}-\mathrm{PA} 2=4,3333 ; \mathrm{M}-\mathrm{PA} 3=$ 4,6061; M-PA4=4,5758) memiliki mean yang lebih besar dibandingkan dengan penggunaan stimulus kondisi Rp 50.000.000,00 (lima puluh juta rupiah) dengan source of message dari Bank Indonesia (M-PA1= 3,6364; M-PA2= 3,8485; M-PA3= 4,5152; M-PA4= 4,4242).

Penelitian ini menemukan bahwa iklan dengan sumber pesan dari Komisi Pemberantasan Korupsi (KPK) dalam kondisi Rp 100.000.000,00 (seratus juta rupiah) dianggap lebih efektif dalam mempengaruhi penerimaan publik (PA3, PA4) secara signifikan. Temuan dalam penelitian ini bahwa iklan pembatasan 
transaksi tunai dengan source of message dari Komisi Pemberantasan Korupsi (KPK) dalam kondisi Rp 100.000.000,00 (seratus juta rupiah) dianggap lebih efektif dalam mempengaruhi penerimaan publik (public acceptance) secara signifikan.

Begitu juga iklan dengan sumber pesan dari Komisi Pemberantasan Korupsi (KPK) dalam kondisi Rp 50.000.000,00 (lima puluh juta rupiah) juga dianggap efektif dalam mempengaruhi penerimaan publik (PA3, PA4) secara signifikan. Temuan dalam penelitian ini bahwa iklan pembatasan transaksi tunai dengan source of message dari Komisi Pemberantasan Korupsi (KPK) dalam kondisi Rp 50.000.000,00 (lima puluh juta rupiah) dianggap efektif dalam mempengaruhi penerimaan publik (public acceptance) secara signifikan.

Secara terperinci stimulus marketing appeals sebagaimana terdapat dalam Tabel 5. diatas dapat dijelaskan bahwa:

a. Mean (rata-rata) dengan skor terbesar terdapat pada PA3 yaitu $(5,1818)$, iklan pembatasan transaksi tunai dengan source of message dari Komisi Pemberantasan Korupsi (KPK)

dalam kondisi Rp 100.000.000,00 (seratus juta rupiah), dan lebih besar dari PA3 iklan pembatasan transaksi tunai dengan source of message dari Komisi Bank Indonesia dalam kondisi Rp 100.000.000,00 (seratus juta rupiah), yaitu $(4,0606)$.

b. Mean (rata-rata) pada urutan kedua terbesar terdapat pada PA4 yaitu (4.8485), yang juga iklan pembatasan transaksi tunai dengan source of message dari Komisi Pemberantasan Korupsi (KPK) dalam kondisi Rp 100.000.000,00 (seratus juta rupiah), dan lebih besar dari PA4 iklan dengan source of message dari Komisi Bank
Indonesia dalam kondisi Rp 100.000.000,00 (seratus juta rupiah), yaitu (4,0606).

c. Iklan pembatasan transaksi tunai dengan mean (rata-rata) pada urutan ketiga terbesar terdapat pada PA3 yaitu $(4,6061)$, dengan source of message dari Komisi Pemberantasan Korupsi (KPK) dalam kondisi Rp 50.000.000,00 (lima puluh juta rupiah), dan lebih besar dari PA3 iklan pembatasan transaksi tunai dengan source of message dari Komisi Bank Indonesia dalam kondisi Rp 50.000.000,00 (lima puluh juta rupiah), yaitu $(4,5152)$.

d. Iklan pembatasan transaksi tunai dengan mean (rata-rata) pada urutan ke empat terbesar terdapat pada PA4 yaitu $(4,5758)$, dengan source of message dari Komisi Pemberantasan Korupsi (KPK) dalam kondisi Rp 50.000.000,00 (lima puluh juta rupiah), dan lebih besar dari PA4 iklan pembatasan transaksi tunai dengan source of message dari Komisi Bank Indonesia dalam kondisi, yaitu $(4,4242)$.

e. Mean (rata-rata) pada urutan kelima terbesar terdapat pada PA2 yaitu (4.4242), yang juga merupakan iklan pembatasan transaksi tunai dengan source of message dari Komisi Pemberantasan Korupsi (KPK) dalam kondisi Rp 100.000.000,00 (seratus juta rupiah), dan lebih besar dari PA2 iklan pembatasan transaksi tunai dengan source of message dari Komisi Bank Indonesia dalam kondisi Rp 100.000.000,00 (seratus juta rupiah), yaitu $(3,0909)$.

f. Iklan pembatasan transaksi tunai dengan mean (rata-rata) pada urutan ke enam terbesar terdapat pada PA2 yaitu (4.3333), dengan source of message dari Komisi Pemberantasan Korupsi (KPK) dalam kondisi Rp 50.000.000,00 
(lima puluh juta rupiah), dan lebih besar dari PA3 iklan pembatasan transaksi tunai dengan source of message dari Komisi Bank Indonesia dalam kondisi Rp 50.000.000,00 (lima puluh juta rupiah), yaitu $(3,8485)$

g. Mean (rata-rata) pada urutan ketujuh terbesar terdapat pada PA1 yaitu $(4,2727)$, yang juga merupakan iklan pembatasan transaksi tunai dengan source of message dari Komisi Pemberantasan Korupsi (KPK) dalam kondisi Rp 100.000.000,00 (seratus juta rupiah), dan lebih besar dari PA1 iklan pembatasan transaksi tunai dengan source of message dari Komisi Bank Indonesia dalam kondisi Rp 100.000.000,00 (seratus juta rupiah), yaitu $(3,0303)$.

h. Iklan pembatasan transaksi tunai dengan mean (rata-rata) pada urutan ke delapan terbesar terdapat pada PA1 yaitu $(4,2424)$, dengan source of message dari Komisi Pemberantasan Korupsi (KPK) dalam kondisi Rp 50.000.000,00 (lima puluh juta rupiah), dan lebih besar dari PA1 iklan pembatasan transaksi tunai dengan source of message dari Komisi Bank Indonesia dalam kondisi Rp 50.000.000,00 (lima puluh juta rupiah), yaitu $(3,6364)$.

Dari data hasil analisis statistik deskriptif, uji manipulasi (manipulation check) sebagaimana dalam Tabel 6. diatas, terdapat perbedaan mean (M) dari iklan pembatasan transaksi tunai yang menggunakan kondisi Rp 50.000.000,00 (lima puluh juta rupiah), dengan sumber pesan dari Komisi Pemberantasan Korupsi (KPK), yaitu (M-MC1 = 0,9697; M-MC2 = 1,0000; d a n M-MC3 = 1,0000) yang memiliki mean yang lebih besar dibandingkan dengan penggunaan kondisi Rp 50.000.000,00 (lima puluh juta rupiah) dengan source of message dari Bank
Indonesia $\quad(\mathrm{M}-\mathrm{MC} 1=\quad 0,9697 ; \quad \mathrm{M}-\mathrm{MC} 2=$ 0,9394; dan M-MC3= 0,9394).

Dengan demikian, dalam eksperimen iklan pembatasan transaksi tunai yang menggunakan kondisi Rp 50.000.000,00 (lima puluh juta rupiah), dengan sumber pesan dari Komisi Pemberantasan Korupsi (KPK) hanya ditemukan 1 (satu) partisipan (dari 33 partisipan) yang salah menjawab dalam uji manipulasi (manipulation check), yaitu pada M-MC1 (0,9697).

Sementara dalam eksperimen iklan pembatasan transaksi tunai yang menggunakan kondisi Rp 50.000.000,00 (lima puluh juta rupiah), dengan sumber pesan dari Bank Indonesia ditemukan 5 (lima) partisipan (dari 33 partisipan) yang salah menjawab dalam uji manipulasi (manipulation check), yaitu pada M-MC1= 1 partisipan (0,9697); $\mathrm{M}-\mathrm{MC} 2=2$ partisipan $(0,9394)$ dan M-MC3= 2 partisipan $(0,9394)$.

Sedangkan dari data hasil analisis statistik deskriptif, untuk uji manipulasi (manipulation check) sebagaimana dalam Tabel 6. diatas, terdapat perbedaan mean (M) dari iklan pembatasan transaksi tunai yang menggunakan kondisi Rp. 100.000.000,- (seratus juta rupiah), dengan sumber pesan dari Komisi Pemberantasan Korupsi (KPK), yaitu (M-MC1 = 0,9091; M-MC2 $=0$, 9697; $d$ a n M-MC3 $=0$, 9091) yang memiliki mean yang lebih besar dibandingkan dengan penggunaan kondisi Rp 100.000.000,00 (seratus juta rupiah) dengan source of message dari Bank Indonesia (MMC1 $=0,6970 ; \mathrm{M}-\mathrm{MC} 2=0,9697$; dan $\mathrm{M}-$ MC3 $=0,9091$ ).

Dengan demikian, dalam eksperimen iklan pembatasan transaksi tunai yang menggunakan kondisi Rp 100.000.000,00 (seratus juta rupiah), dengan sumber pesan dari Komisi Pemberantasan Korupsi (KPK) hanya ditemukan 7 (tujuh) partisipan (dari 33 partisipan) yang salah menjawab dalam 
uji manipulasi (manipulation check), yaitu pada M-MC1 = 3 partisipan (0,9091); MMC2 $=1$ partisipan $(0,9697)$ dan M-MC3 = 2 partisipan $(0,9091)$. Sementara dalam eksperimen iklan pembatasan transaksi tunai yang menggunakan kondisi Rp 100.000.000,00 (seratus juta rupiah), dengan sumber pesan dari Bank Indonesia ditemukan 10 (sepuluh) partisipan (dari 33 partisipan) yang salah menjawab dalam uji manipulasi (manipulation check), yaitu pada M-MC1 = 6 partisipan $(0,6970)$; MMC2 = 1 partisipan $(0,9697)$ dan M-MC3 = 3 partisipan $(0,9091)$.

Berdasarkan eksperimen penelitian yang dikembangkan maka dapat memperkuat konsep-konsep teoritis dan memberikan dukungan empiris terhadap penelitian terdahulu. Literatur-literatur yang menjelaskan tentang kreativitas iklan dan kredibilitas endorser terhadap daya tarik iklan, efektifitas iklan, dan sikap terhadap iklan telah diperkuat keberadaannya oleh konsep-konsep teoritis dan dukungan empiris mengenai hubungan-hubungan kausalitas dan variabel-variabel yang mempengaruhi efektifitas iklan. Selanjutnya efektifitas iklan akan mempengaruhi penerimaan publik (public acceptance) terhadap iklan pembatasan transaksi tunai.

Dalam penelitian ini ditemukan bahwa marketing appeals iklan pembatasan transaksi tunai yang menggunakan source of message (sumber pesan) Komisi Pemberantasan Korupsi (KPK) sebagai Policy Benefit Institution diperoleh hasil dengan skor lebih tinggi dibandingkan dengan source of message (sumber pesan) Bank Indonesia (BI) sebagai Policy Execution Institution baik dalam kondisi Rp 50.000.000,00 (lima puluh juta rupiah) maupun kondisi Rp 100.000.000,00 (seratus juta rupiah). Dimana hasil data dari analisa statistik deskriptif bahwa iklan pembatasan transaksi tunai yang menggunakan source of message (sumber pesan) Komisi Pemberantasan Korupsi diperoleh hasil dengan hasil lebih tinggi dan dianggap lebih efektif dalam mempengaruhi penerimaan publik (public acceptance) di Indonesia dibandingkan dengan penggunaan source of message (sumber pesan) Bank Indonesia.

Hasil penelitian ini secara empiris memperkuat pendapat Kotler (2004), tentang memformulasikan isi pesan yang terbaik harus mencari tahu daya tarik, tema, ide atau unique selling proposition (USP). Ada tiga jenis daya tarik yaitu daya tarik rasional, daya tarik emosional dan, daya tarik moral. Hasil penelitian ini juga secara empiris memperkuat teori Belch \& Belch (2004) tentang beberapa tipe umum dalam message appeal, yaitu pesan yang disampaikan oleh sumber yang menarik atau populer terbukti lebih diperhatikan dan diingat audience, karena faktor yang membuat sumber dianggap kredibilitas adalah:

a. Keahlian, yaitu pengetahuan khusus yang dimiliki penyampai pesan yang dianggap mendukung pesan.

b. Kepercayaan, yaitu seberapa dipercayanya penyampai pesan oleh audience.

c. Ketertarikan/kesukaan, yaitu yang dicapai melalui kejujuran, humor dan kewajaran.

\section{KESIMPULAN DAN SARAN}

Berdasarkan analisis statistik deskriptif dalam penelitian eksperimen ini, maka paper ini dapat memberikan beberapa kesimpulan. Kesimpulan pertama, secara umum marketing appeals iklan pembatasan transaksi tunai yang menggunakan source of message (sumber pesan) Komisi Pemberantasan Korupsi (KPK) sebagai Policy Benefit Institution diperoleh hasil dengan skor lebih tinggi dibandingkan dengan source of message (sumber pesan) 
Bank Indonesia (BI) sebagai Policy Execution Institution baik dalam kondisi Rp 50.000.000,00 (lima puluh juta rupiah) maupun kondisi Rp 100.000.000,00 (seratus juta rupiah). Dimana hasil data dari analisa statistik deskriptif bahwa iklan pembatasan transaksi tunai yang menggunakan source of message (sumber pesan) Komisi Pemberantasan Korupsi diperoleh hasil dengan hasil lebih tinggi dan dianggap lebih efektif dalam mempengaruhi penerimaan publik (public acceptance) di Indonesia dibandingkan dengan penggunaan source of message (sumber pesan) Bank Indonesia.

Kesimpulan kedua, dari hasil analisis statistik deskriptif dalam penelitian ini juga diperoleh hasil bahwa marketing appeals iklan pembatasan transaksi tunai dalam kondisi Rp 100.000.000,00 (seratus juta rupiah) dengan menggunakan source of message (sumber pesan) Komisi Pemberantasan Korupsi (KPK) mempunyai skor yang lebih tinggi pada hampir semua dependent variable penerimaan publik (public acceptance) dan berpengaruh sangat efektif terhadap penerimaan publik (public acceptance) di Indonesia dibandingkan dengan kondisi Rp 50.000.000,00 (lima puluh juta rupiah) dengan menggunakan source of message (sumber pesan) Komisi Pemberantasan Korupsi dan sumber pesan (source of message) dari Bank Indonesia baik dalam kondisi Rp 50.000.000,00 (lima puluh juta rupiah) maupun kondisi Rp 100.000.000,00 (seratus juta rupiah).

Kesimpulan ketiga, dari hasil analisis statistik deskriptif perbandingan masing-masing uji manipulasi (manipulation check) diperoleh hasil bahwa dalam eksperimen iklan pembatasan transaksi tunai yang menggunakan kondisi Rp 50.000.000,00 (lima puluh juta rupiah) dengan sumber pesan dari Komisi Pemberantasan Korupsi (KPK) hanya ditemukan 1 (satu) partisipan (dari 33 partisipan) yang salah menjawab dalam uji manipulasi (manipulation check). Sementara dalam kondisi Rp 50.000.000,00 (lima puluh juta rupiah) dengan sumber pesan dari Bank Indonesia ditemukan 5 (lima) partisipan (dari 33 partisipan) yang salah menjawab dalam uji manipulasi (manipulation check). Sedangkan dalam kondisi Rp 100.000.000,00 (seratus juta rupiah) dengan sumber pesan dari Komisi Pemberantasan Korupsi (KPK) hanya ditemukan 7 (tujuh) partisipan (dari 33 partisipan) yang salah menjawab dalam uji manipulasi (manipulation check) dan kondisi Rp 100.000.000,00 (seratus juta rupiah), dengan sumber pesan dari Bank Indonesia ditemukan 10 (sepuluh) partisipan (dari 33 partisipan) yang salah menjawab dalam uji manipulasi (manipulation check).

Berdasarkan hasil dan analisis yang telah dilakukan, penelitian ini memberikan saran-saran sebagai berikut:

a. Marketing appeals iklan pembatasan transaksi tunai dalam kondisi Rp 100.000.000,00 (seratus juta rupiah) dengan source of message (sumber pesan) Komisi Pemberantasan Korupsi (KPK) mempunyai skor yang lebih tinggi pada hampir semua dependent variable penerimaan publik (public acceptance) dan berpengaruh sangat efektif terhadap penerimaan publik (public acceptance) di Indonesia. Oleh karena itu pemerintah dan pihak terkait lainnya dapat mempertimbangkan hasil eksperimen ini dalam melaksanakan sosialisasi ide pembatasan transaksi tunai di Indonesia. Demikian juga halnya dalam perumusan dan membuat peraturan/perundangundangan pembatasan transaksi tunai di Indonesia.

b. Dari hasil analisis statistik deskriptif, menunjukkan bahwa hampir semua dependent variable penerimaan publik 
(public acceptance) terutama PA3 (Mendukung Pembatasan Transaksi Tunai) dan PA4 (Bersedia Menandatangani Petisi) memiliki mean dengan skor sangat tinggi, sehingga pemerintah dan pihak terkait perlu mengambil langkah-langkah dan kebijakan strategis untuk mewujudkan pembatasan transaksi tunai di Indonesia.

c. Dalam hasil analisis statistik deskriptif perbandingan masing-masing uji manipulasi (manipulation check) masih masih terdapat adanya kesalahan jawaban dalam uji manipulasi (manipulation check), terutama menyangkut jumlah pembatasan dan tujuan pembatasan transaksi tunai. Untuk itu pemerintah dan pihak terkait lainnya perlu melakukan sosialisasi secara kontinu kepada rakyat Indonesia melalui berbagai media.

Penelitian ini masih memiliki keterbatasan-keterbatasan, dimana dengan keterbatasan ini diharapkan dapat dilakukan perbaikan untuk kesempurnaan pada penelitian yang akan datang. Yang merupakan keterbatasan dalam penelitian ini, dimana hanya menggunakan source of message (sumber pesan) dari Komisi Pemberantasan Korupsi (KPK) dan Bank Indonesia (BI). Sementara untuk source of message (sumber pesan) juga dapat menggunakan Pusat Pelaporan dan Analisa Transaksi Keuangan (PPATK), Kementerian Koordinator Bidang Perekonomian, Kementerian Keuangan, Otoritas Jasa Keuangan, Kementerian Hukum dan Hak Asasi Manusia, Kejaksaan Agung, Mahkamah Agung, Kepolisian Negara Republik Indonesia, Badan Pemeriksan Keuangan, Unit Kerja Presiden Bidang Pengawasan dan Pengendalian Pembangunan (UKP4), dan lain-lain.

Sedangkan untuk marketing appeals, sebagaimana dalam teori Bovee (1996), Belch \& Belch (2004), Kotler (2004) dan berdasarkan penelitian-penelitian sebelumnya, masih banyak terdapat unsurunsur marketing appeals seperti media appeals, rational appeals, self-benefit appeals, other-benefit appeals, dan unsur marketing appeals lainnya. Untuk itu pada penelitian selanjutnya diharapkan dapat menambah beberapa variable lain yang memungkinkan dapat mempengaruhi penerimaan publik dan mampu mengembangkan konseptual dan permodelan kajian kajian ini yang lebih luas. 


\section{DAFTAR PUSTAKA}

Alifahmi, Hifni. 2005. Sinergi Komunikasi Pemasaran, Integrasi Iklan, Publik Relations dan Promosi, Jakarta: Quantum.

Agustina, Rosa. 2003. Perbuatan Melawan Hukum, Jakarta: Fakultas Hukum Universitas Indonesia.

Arifin, Johan. 2000. Korupsi dan Upaya Pemberantasannya Melalui Strategi Auditing, Jakarta: Media Akuntansi.

Arikunto, Suharsimi, 2009, Prosedur Penelitian, Suatu Pendekatan Praktik, Jakarta: Rineka Cipta.

Asian Development Bank (2003), Manual on Countering Money Laundering and The Financing of Terrorism, $22 \quad$ Nopember 2012, http://www2.adb.org/documents/manuals/countering_money laundering/prelim.pdf

Bank Indonesia, 2001, "Prinsip Mengenal Nasabah (Know Your Customer) dan Anti Pencucian Uang (AntiMoney Laundering)", 10 Nopember 2012, http://www.bi.go.id/web/id/Perbankan/Prinsip+Mengenal+Nasabah+dan+Anti+Pencucian+Uang

Bank for International Settlements, 1998, Prevention of Criminal Use of the Banking System for the Purpose of Money-Laundering, 12 Nopember, 2012, www.bis.org/publ/bcbsc137.pdf

Belch, George E, \& Michael A. Belch, 2004, Advertising and Promotion: An intergrated Marketing Communications Perspective (6th ed.), New York: McGraw Hill.

Buku Saku Korupsi 2003, Memahami Untuk Membasmi, Jakarta: Komisi Pemberantasan Korupsi Republik Indonesia.

Bucy, Pamela, H. 1992, White Collar Crime: Cases and Materials. St. Paul, Minn: West Publishing Co.

Corruption Perceptions Index, 2011. Corruption Perceptions Index,19 Nopember 2012, http://cpi.transparency.org/cpi2011/results/=

Cooper Donald R, Schindler Pamela S, 2006, Metode Riset Bisnis, Volume 1, Edisi 9, dan Volume 2, Edisi 9, Jakarta: PT Media Global Edukasi.

Durianto, Darmadi, Sugiarto, Tony Sitinjak, 2001, Menaklukan Pasar Melalui Riset Ekuitas dan Perilaku Merek, Jakarta: PT Gramedia Pustaka Utama.

Emzir, 2009, Metodologi Penelitian Pendidikan, Kuantitatif dan Kualitatif, , Jakarta: Raja Grafindo Persada.

European Union, 2012, Commissioner Michel Barnier welcomes the adoption of revised international standards in support of the fight against Money Laundering and Terrorist Financing, 24 Nopember 2012, http://europa.eu/rapid/press-release_MEMO-12-113_en.htm?locale=en

Fadjar, Abdul Mukthie, 2002, Reformasi Konstitusi Dalam Masa Transisi Paradigmatik, Jakarta: Pustaka Sinar Harapan.

Fajar, Asep Rahmat 2002, Potret Dunia Peradilan Indonesia, Refleksi dan Proyeksi,. Media Hukum dan Keadilan Teropong, Masyarakat Pemantau Peradilan Indonesia, Jakarta: FHUI.

Ferdinand, Augusty, 2006, Metode Penelitian Manajemen, Edisi 2, Semarang: Badan Penerbit Universitas Diponegoro.

Financial Action Task Force, 2003, 40 Recommendations and Basel Committee on Banking Supervision, 12, Nopember, 2012, http://www.fatfgafi.org/media/fatf/documents/FATF\%20Standards\%20-\%2040\%20Recommendations\%20rc.pdf 2012, FATF Members and Observers,30 Nopember2012,http://www.fatfgafi.org/pages/aboutus/membersandobservers/

Financial Crime Prevention Project, 2006, Manual Pelatihan dan Persiapan Ujian CFE (Certified Fraud Examiner) untuk KPK, BPK, PPATK, Inspektorat Jenderal dan Kejaksaan Agung.

Ganarsih, Yenti, 2009, Kriminalisasi Pencucian Uang (Money Laundering), Jakarta: FHUI.

Ghozali, Imam, 2005, Aplikasi Analisis Multivariate dengan Program SPSS, Semarang: Badan Penerbit Universitas Diponegoro. 
Gunawan, Andri, 2013, Pembatasan Transaksi Tunai Cegah Peluang Korupsi, 28 Maret 2013, http://www.hukumonline.com/berita/baca/lt5146c85fc3821/pembatasan-transaksi-tunai-cegahpeluang-korupsi

Hadad, D, Muliawan, 2012, BI Pastikan Batasi Transaksi Tunai,16 Nopember 2012, http://bisnis.news.viva.co.id/news/read/294110-transaksi-tunai-dibatasi--bi-beri-masukan-dpr

Hamzah, M, Chandra, 2011, Pembatasan Transaksi Tunai Permudah Basmi Korupsi, 24 Nopember 2012, http://www.mediaindonesia.com/read/2011/10/27/271734/284/1/Pembatasan-TransaksiTunai-Permudah-Basmi-Korupsi

Hannagan, T.J, 1992, Marketing for Non-Profit Sector, London: Mcmillan Press Ltd. Hartati,

Evi, 2005, Tindak Pidana Korupsi, Semarang: Sinar Grafika.

Husein, Yunus, 2003, RAHASIA BANK: Privasi Versus Kepentingan Umum, Jakarta: Pascasarjana FH UI.

Indrayana, Denny 2005, Negara dalam Darurat Korupsi, Jakarta: Sinar Grafika.

Jefkins, Frank, 1996, Periklanan, Jakarta: Erlangga.

Kasali, Rhenald, 1995, Manajemen Periklanan: Konsep dan Aplikasinya di Indonesia, Jakarta: Pustaka Grafiti.

Komisi Pemberantasan Korupsi, 2002, Undang-Undang No. 20 Tahun 2001 Tentang Pemberantasan Tindak Pidana Korupsi, 17 Nopember 2012, http://www.kpk.go.id/uploads/PDdownloads/uu302002.pdf

Kotler, Philip, 1989, Social Marketing: Strategies for Changing Public Behaviour, New York: The Free Press.

, 1999, Marketing Mangement (2nd ed.), New Jersey: Prentice Hall.

2000, Manajemen Pemasaran, Jilid 2, Jakarta, Bumi Aksara.

,2002, Social Marketing: Improving The Quality of Life Second Edition. Sage Publications, Inc.

, 2009, Manajemen Pemasaran: Analisis, Perencanaan Implementasi dan Kontrol, Jakarta: PT. Prenhallindo.

Lilley, Peter, 2003, Dirty Dealing: The Untold Truth About Global Money Laundering, International Crime and Terrorism, London and Sterling, VA: Kogan Page Limited.

Lopa, Baharudin, 1992, Kejahatan Korupsi dan Penegakan Hukum, Jakarta: Rineka Cipta.

Mahkamah Konstitusi, 2010, Putusan Mahkamah Konstitusi, Putusan Nomor 37-39/PUU-VIII/2010, hal:38, $24 \quad$ Nopember 2012, http://www.mahkamahkonstitusi.go.id/Sinopsis/sinopsis_Putusan\%2037-39-PUU2010\%20_Komisi\%20Pemberantasan\%20Tindak\%20Pidana\%20K.pdf

Malhotra, Naresh K, 2007, Marketing Research: an Applied Orientation (5th ed.), New Jersey: Pearson.

Peraturan Bank Indonesia, Nomor: 11/28/PBI/2009, Penerapan Program Anti Pencucian Uang dan Pencegahan Pendanaan Terorisme Bagi Bank Umum,25 Nopember 2012. http://www.bi.go.id/NR/rdonlyres/3D8D2600-2699-4D04-A19331C49C1D052F/17234/pbi_112809.pdf

Peraturan Bank Indonesia, Nomor: 12/20/PBI/2010, Penerapan Program Anti Pencucian Uang (APU) dan Pencegahan Pendanaan Terorisme (PPT) bagi Bank Perkreditan Rakyat dan Bank Pembiayaan Rakyat Syariah, $25 \quad$ Nopember 2012, http://www.bi.go.id/web/id/Peraturan/Perbankan/pbi_122010.htm

Pusat Pelaporan dan Analisis Transaksi Keuangan, 2011, Undang-Undang tentang Pencucian Uang, 25 Nopember 2012, http://www.ppatk.go.id/pages/view/17

Qamarius, Ibrahim, 2011, Pembatasan Transaksi Tunai Solusi Pemberantasan Korupsi dan Pencucian Uang Lainnya,14 Nopember 2012, http://ekonomi.kompasiana.com/moneter/2011/07/30/pembatasan-transaksi-tunai-solusipemberantasan-korupsi-dan-pencucian-uang-lainnya , 2011, Pemaafan Nasional Bersyarat untuk Pemberantasan Korupsi di Indonesia,14 
nasional-bersyarat-untuk- pemberantasan-korupsi-di-indonesia-broleh--ibrahim-qamarius-

Rajagukguk, Erman, 2011, Butir-Butir Hukum Ekonomi, Jakarta: Lembaga Studi Hukum dan Ekonomi FHUI.

Shimp, A Terence, 2003, Periklanan Promosi, Aspek Tambahan Komunikasi Pemasaran Terpadu, Jilid 1, Edisi Kelima, Jakarta: Erlangga.

Sulaksana, Uyung, 2003, Integrated Marketing Comunications, Yogyakarta: Pustaka Fajar.

Sutedi, Adrian, 2006, Hukum Perbankan, Jakarta: Sinar Grafika.

Windahl, Sven et. al, 1992, Using Communication Theory-An Introduction to Planned Communication, London: SAGE Publication.

World Bank, 2003, Basel Committee on Banking Supervision-Bank For International Settlements, 15 Nopember 2012, http://www1.worldbank.org/finance/assets/images/11-annex01-f.qxd.pdf 